NBER WORKING PAPER SERIES

POLITICAL RESERVATIONS AND WOMEN'S ENTREPRENEURSHIP IN INDIA

\author{
Ejaz Ghani \\ William R. Kerr \\ Stephen D. O'Connell \\ Working Paper 19868 \\ http://www.nber.org/papers/w19868 \\ NATIONAL BUREAU OF ECONOMIC RESEARCH \\ 1050 Massachusetts Avenue \\ Cambridge, MA 02138 \\ January 2014
}

We thank Nina Pavcnik, David McKenzie, Petia Topalova, and two referees for helpful comments on this work. We also thank Mani Shankar Iyer, Pratap Banhu Mehta, Meera Chatterjee, Prabir De, Ria Mukherji, Reema Nanavaty, Bhishma Rout, and Nupur Tiwary for extremely useful discussions on Panchayati Raj Institutions. We thank the World Bank's South Asia Labor Flagship team for providing the primary datasets used in this paper. We are particularly indebted to Shanthi Nataraj for sharing her wisdom regarding the industrial survey data during the nascent stages of this work. Funding for this project was provided by World Bank and the Multi-Donor Trust Fund for Trade and Development. Our online appendix that contains additional materials noted throughout this study and code for replicating the analysis is available at Stephen O'Connell's website. The views expressed here are those of the authors and not of any institution they may be associated with. The views expressed herein are those of the authors and do not necessarily reflect the views of the National Bureau of Economic Research.

NBER working papers are circulated for discussion and comment purposes. They have not been peerreviewed or been subject to the review by the NBER Board of Directors that accompanies official NBER publications.

(C) 2014 by Ejaz Ghani, William R. Kerr, and Stephen D. O'Connell. All rights reserved. Short sections of text, not to exceed two paragraphs, may be quoted without explicit permission provided that full credit, including $\odot$ notice, is given to the source. 
Political Reservations and Women's Entrepreneurship in India

Ejaz Ghani, William R. Kerr, and Stephen D. O'Connell

NBER Working Paper No. 19868

January 2014

JEL No. D22,E26,H11,J16,L10,L26,L60,M13,O10,R00,R10,R12

\begin{abstract}
$\underline{\text { ABSTRACT }}$
We quantify the link between the timing of state-level implementations of political reservations for women in India with the role of women in India's manufacturing sector. While overall employment of women in manufacturing does not increase after the reforms, we find significant evidence that more women-owned establishments were created in the unorganized/informal sector. These new establishments were concentrated in industries where women entrepreneurs have been traditionally active and the entry was mainly found among household-based establishments. We measure and discuss the extent to which this heightened entrepreneurship is due to channels like greater finance access or heightened inspiration for women entrepreneurs.
\end{abstract}

Ejaz Ghani

South Asia PREM

The World Bank

Washington D.C.

Eghani@worldbank.org

William R. Kerr

Harvard Business School

Rock Center 212

Soldiers Field

Boston, MA 02163

and NBER

wkerr@hbs.edu
Stephen D. O'Connell

City University of New York

Department of Economics

The Graduate Center

365 Fifth Ave

New York, NY 10016-4309

soconnell@gc.cuny.edu 


\section{Introduction}

The implementation of political reservations for women in India has been proven to affect many aspects of the economic, political, and social lives of women. A brief review, which we expand upon further below, links these reservations to greater local investment in infrastructure and related public goods valued by women (Chattopadhyay and Duflo 2004b), improved perceptions of women by men when exposed to women in leadership roles and greater aspirations for younger women (Beaman et al. 2009, 2012), greater reporting of crimes against women (Iyer et al. 2012), and more. Moreover, the available evidence suggests these effects persist (e.g., Deininger et al. 2011). This literature is among the most powerful evidence assembled for the significant economic benefits of gender equality (Duflo 2005, 2011, Klapper and Parker 2011, World Bank 2012).

This paper contributes to the literature by looking at an underexplored issue of the link between political and economic empowerment. What role, if any, have these political reservations had for women's participation in the workforce? Despite the many positive impacts associated with these reforms, their contributions to promoting women's engagement in the local economy remain uncertain. These relationships are critical for identifying the short- and longterm impact of such policies. Significant empowerment of women in the workforce and as business owners may be the strongest mechanism possible for entrenching and amplifying the positive impacts associated with these political reservations.

We consider in particular the role of women in the manufacturing sector from 1994 to 2005. The unorganized sector of Indian manufacturing is comprised of establishments with fewer than 10 employees (or fewer than 20 if the establishment does not use electricity). Our data report gender-based ownership and employment in unorganized manufacturing establishments by state and industry in 1994, 2000 and 2005. The unorganized sector is of particular interest as it has constituted approximately $99 \%$ and $80 \%$ of total manufacturing establishment counts and employment in India consistently since the early 1990s. We also observe gender-based employment in the organized sector, which is comprised of all plants above the indicated employment thresholds. On the whole, the female ownership share of Indian manufacturing business more than doubled during our period of study: in 1994, female-owned businesses comprised $9 \%$ of total manufacturing employment; by 2005 , this share had grown tremendously 
to $19 \%$ (Ghani et al. 2013c). Therefore it is of crucial importance to understand more deeply the factors that have contributed to this sharp emergence of female entrepreneurship and business ownership over a relatively short time period.

Our empirical strategy follows Iyer et al. (2012) by using differences in the timing of the implementation of reservations across Indian states. We conduct a panel analysis at the stateindustry level that allows us to exploit this state-level timing variation and differences in traits across industries. Industries are defined at the three-digit level within the manufacturing sector. Empirical results yield a mixed message regarding the extent to which these reforms improved women's participation in the workforce. On one hand, we do not identify that women's employment in manufacturing increased after the implementation of reservations. This limited response is true in both the unorganized and organized sectors, is observed in multiple datasets, and it holds for employment in both female- and male-owned establishments.

On the other hand, we find significant evidence that women's entrepreneurship in India increased with the implementation of political reservations. This increase occurs with a statelevel timing that follows the implementation of the reservations, and the growth persists even after controlling for contemporaneous male entrepreneurship by state-industry. We also show that the state-level timing of the implementations was not linked to pre-existing differences in entrepreneurship by state, further adding to the plausible exogeneity introduced by Iyer et al. (2012), and that there is no evidence of pre-trends in the age structures of women-owned manufacturing businesses in 1994. We describe below, however, some important limitations in the degree to which we can fully measure pre-trends, with our evidence often being indirect.

We also see evidence of this entrepreneurship response when looking along state borders as to how long adjacent district pairs have been exposed to the reservations. This state border strategy helps with omitted concerns, but it is not a panacea for all potential identification challenges. The approach better controls for local differences in income, climate, culture, social norms, and demographics, for example, to the degree to which these factors are common between neighboring districts. Also, the approach requires that identification come through differential changes for states on one border versus another that are appropriately timed with the adoption of reservations. However, the approach may not isolate the impact of the reservations from other changes that states may have been made with similar timing. Thus, if the political 
reservations were consistently bundled into a package of reforms implemented by states (e.g., alongside large independent investments in women's education), the border approach will not be able to differentiate the specific role of the reservations.

We further investigate the channels through which this entrepreneurship flourishes. The heightened start of women-owned establishments is concentrated in industrial sectors in which women have traditionally owned establishments. Equally as important, the greater entrepreneurship is mostly concentrated in household-based enterprises, rather than establishments opening as independent facilities.

We then discuss the potential channels through which this effect occurs, providing both quantitative and qualitative evidence. We do not find much evidence that the entrepreneurship is linked to changes in reporting or to greater access to government-sponsored contracts and business. Likewise, improved financing conditions appear to play a modest role, as the increase in female-owned loan-holding establishments is weaker than the total effect registered and suggests that financing accompanied the increased entry rather than caused it. We then discuss how entry patterns could be consistent with increases at the local level of public goods and infrastructure favored by women (e.g., Pande 2003, Besley et al. 2004, Chattopadhyay and Duflo 2004a,b) or greater aspirations of women towards entrepreneurship (e.g., Beaman et al. 2012). We discuss how these stimuli could have produced the industry patterns observed, to the extent that women entrepreneurs built upon sectors where women have traditionally been active (e.g., Ghani et al. 2013a) and at a household-based scale of operation that was feasible to achieve.

This study contributes to three strands of academic literature. Most directly, our work connects to prior studies of the impact of political reservations for India and women's economic outcomes. To our knowledge, we are the first in this literature to quantify the entrepreneurship effects in a panel setting that uses state-level variation in implementation timings for identification, with Beaman et al. (2010) providing related evidence using micro-data from West Bengal. ${ }^{1}$ Second, our work builds upon prior studies of gender differences in entrepreneurship ${ }^{2}$

${ }^{1}$ Beaman et al. (2010) show an increase in the number of self-help groups with their own bank accounts after the implementation of reservations, and that these groups had on average larger bank accounts. To the extent to which these self-help groups are associated with more entrepreneurship, this increase would be consistent with our findings. We further discuss this study below. 
and studies of the spatial distribution of entrepreneurship in India. ${ }^{3}$ Third, and more broadly, we contribute to a larger literature on women's advancement. ${ }^{4}$

These findings are also important for Indian policy makers and business leaders. By 2011, India had achieved significant acknowledgement for the level of gender parity in political participation and empowerment. For example, India ranked 19th out of 135 countries in women's political empowerment in the 2011 Global Gender Gap Report (Hausmann et al. 2011). Yet despite India's many economic advancements since liberalization began, the role of women in the Indian economy still lags well behind that of advanced economies. This paper quantifies the strengths and limits of the political reservations in closing this gap.

The next section of this paper describes the political reservations enacted in India and the state-level implementations that we exploit. Section 3 outlines our data and provides some basic descriptive statistics, and Section 4 provides evidence on the exogenous timing of the political reservations to the women's entrepreneurship that we study. Section 5 provides our core empirical analysis, and Section 6 discusses the potential mechanisms behind our results. The last section concludes.

\section{Political Reservations for Women in India}

\section{History of Political Reservations}

The increased role and status of women seen in the $20^{\text {th }}$ century has contributed substantially to the changing economic and political fabric of developing and developed countries alike. While much of this progress has come about organically, many governments have implemented policies to increase the speed at which gender parity is achieved along various social and economic dimensions. One popular policy has been the reservation of positions for women (quotas) within governmental bodies. In particular, there have been significant efforts in recent decades to

\footnotetext{
${ }^{2}$ Examples of this work include Rosenthal and Strange (2012), Estrin and Mickiewicz (2011), Minniti (2009, 2010), and Minniti and Naudé (2010). Parker (2009) and Klapper and Parker (2011) offer a comprehensive review of this literature and further references.

${ }^{3}$ Ghani et al. (2013b) and Mukim (2011) provide spatial analyses of manufacturing entrepreneurship in India with our data, and Ghani et al. (2013a) consider gender differences in entrepreneurship for India specifically.

${ }^{4}$ Examples include Mammen and Paxson (2000), Dhaliwal (2000), Mitra (2002), Ghosh and Cheruvalath (2007), Amin (2010), Field et al. (2010), Pillania et al. (2010), Jensen (2010), Verheul et al. (2006), Bruhn (2009), Munshi (2011), Kobeissi (2010), and World Bank (2008).
} 
increase the political participation of women in countries where women's involvement in politics has traditionally been low: by 2001, quotas for women in parliaments were in force in more than 30 countries (Duflo 2005).

India presents one such case: at the national level, reservations for women in elected bodies originated with the $73^{\text {rd }}$ and $74^{\text {th }}$ Indian Constitutional Amendment Acts. These Amendments gave national support to the formalization and implementation of an historical decentralized governance structure known as the panchayat (or, more formally, Panchayati Raj Institutions). Traditionally, panchayats operated at the village level and consisted of a small number of individuals chosen by a village to oversee various local affairs. However, panchayats were not standardized in their structures, organization, operations, or responsibilities, nor were they necessarily elected bodies. By the mid- $20^{\text {th }}$ century, panchayats were widely recognized to embody "concealed forms of social prejudice, oppression, and exploitation that were firmly rooted in local power structures" (GOI 2008). In the latter half of the $20^{\text {th }}$ century, there was support for the revival of a reformed system, with some states indeed restructuring their local government systems to provide for the decentralized panchayat system. By 1989 there was strong support at the national level to give constitutional status to a broadly-implemented panchayat system.

In 1993, two pieces of national legislation came into effect: the $73^{\text {rd }}$ Constitutional Amendment Act instituted a three-tiered system of local government at the village, sub-district (block), and district levels in rural areas of the country, while the $74^{\text {th }}$ Constitutional Amendment Act instituted a revised local governance structure in municipalities (hereafter referred to as "the Amendments"). The Amendments intended to provide large-scale devolution and decentralization of powers to the local bodies. Responsibilities of the panchayat include administration of state transfer programs, planning and implementation of schemes for economic development, establishment and administration of local public goods such as educational and medical facilities, oversight of local infrastructure (water, sewage, roads, etc.), and the monitoring of civil servants (Duflo 2005). Furthermore, the Amendments stipulated that members of the local governance bodies were to be elected at five-year intervals, and at least one-third of all seats at each governance level were required to be filled by women. 
The Amendments required states to adjust or amend local elections to comply with the provisions of the Amendments, and all states amended existing laws or passed new laws to be compliant within one year of the passing of the Amendments. Compliant elections were eventually held by most states/union territories (UTs), and there was considerable variation in the timing of "effective implementation" (i.e., the first election held which implemented the provisions of the Amendments) across states. This implementation timing varied exogenously primarily due to state authorities waiting for the term of existing elected local governing bodies to expire before conducting compliant elections. Upon implementation, local bodies were randomized for the initial implementation of the reservation system such that the one-third goal of seats for women was reached. For each appropriate level of government, the reservations subsequently rotate over the included bodies to maintain the one-third level.

Figure 1 shows the considerable variation in timing of effective implementation of the Panchayati Raj across states/UTs. Beyond the visible variation in timings, two features are important to note. First, two states incorporated provisions regarding political reservations for women before the Amendments. Andhra Pradesh provided for 22\% to 25\% reservations for women in 1964; Karnataka introduced a similar level of reservation for women in 1985 (GOI 2008). ${ }^{5}$ Second, reservations were not implemented in all Indian states/UTs during our sample period. Some states (Meghalaya, Mizoram and Nagaland) were explicitly excluded from the purview of the Amendments. Jammu and Kashmir introduced reservations at a level consistent with the Amendments via state-level legislation, but the election of panchayats under its own Act has not yet taken place. In the empirical section we describe steps to take these features into account. ${ }^{6}$

${ }^{5}$ Kerala and West Bengal restructured their institutions of local government before the passing of the $73^{\text {rd }}$ Act (in 1991 and 1992, respectively), but elections implementing these reservations were not held until after enforcement in 1993. Bihar was prevented from implementation due to legal issues regarding certain provisions of the Amendments (Iyer et al. 2012).

${ }^{6}$ Data on the timing of political reservations comes from several publications documenting the implementation and progress of the reservations (Mathew 1995, 2000; GOI 2008; Iyer et al. 2012). Appendix Table 1 lists years. Beginning with Bihar in 2006, several states increased their reservations for women above the 33\% required by the Amendments. These changes occur after our sample period ends in 2005. 


\section{Literature Review}

A number of studies have examined aspects of the Panchayati Raj and its effect on economic and social outcomes. Using state-level variation in India over four decades, Pande (2003) identifies how the mandated reservations of legislative positions for minority members of Scheduled Caste/Scheduled Tribe (SC/ST) individuals increased the redistribution of resources towards these groups, demonstrating enhanced policy influence. Related, Besley et al. (2004) find that the reservation of leadership positions for SC/ST individuals increased access among SC/ST households to infrastructure or services via government schemes. Chattopadhyay and Duflo (2004a) use information on the location of public goods to show that when an area has leadership positions reserved for SC individuals, the share of public goods going to that group is significantly higher. Chattopadhyay and Duflo (2004b) use village-level variation in political reservations for women to predict the types of public goods provided in 265 reserved and unreserved areas in West Bengal and Rajasthan, finding that leaders invest more in infrastructure that is directly relevant to the needs of their own genders. Ghani, Mani, and O'Connell (2013) find that areas that have had more exposure to women leaders in the Panchayat system allocate a higher share of public works employment to constituent women. This importance of representation to policy outcomes extends to many other contexts (e.g., Powley 2007, Washington 2008, Clots-Figueras 2011). Overall, the studies show the group identity of political leaders matters for the type of public goods provided under the purview of the governing body, with studies using the Indian experience being especially prominent in this literature.

Women leaders may also affect their institutional environment. Topalova and Duflo (2004) find that women leaders in India are less likely to take bribes than their male counterparts. Duflo and Topalova (2004) and Beaman et al. (2009) note that while the public goods provided by reserved women leaders are in greater abundance and at least equal in quality to other villages, residents may express lower satisfaction with the provided goods. Another strand of literature looks at how attitudes towards women change once quota policies are in effect. Hoff and Stiglitz (2010) develop a conceptual framework to show how changes in power, technology, and contacts with the outside world matter especially because they can lead to changes in ideology. Beaman et al. $(2009,2012)$ show how perceptions of women improve once men are 
exposed to women in leadership roles, providing substantial evidence of the framework regarding attitudes and bias implicit in the Hoff and Stiglitz (2010).

Duflo (2005) provides an assessment of the case for political reservations for women and other historically underrepresented groups. Using evidence from India, Duflo (2005) concludes that reservations have been shown to incur a significant reallocation of public goods toward the preferred allocation of the group in power. Pande and Ford (2011) provide a more recent comprehensive review of the literature on gender quotas. They conclude that the political reservations led to a significant increase in women's leadership and influence on policy outcomes, while noting at times more mixed evidence on some outcomes. This review also highlights the need for greater study of economic consequences.

The above studies primarily use the cross-sectional nature of the randomized reservation system to identify treatment effects. However, variation in the timing of the implementation of the $73^{\text {rd }}$ Amendment was also plausibly exogenous, as noted above and further tested later in this paper. Iyer et al (2012) use this state-level variation to investigate the effects of political representation on crime against women, finding significant evidence that political empowerment resulted in greater reporting of crimes against women.

\section{India Manufacturing Data}

Our primary data sources are repeated cross-sectional establishment-level data from surveys of the unorganized manufacturing sector carried out by the Government of India. The data are taken from surveys conducted in fiscal years 1994, 2000, and 2005. ${ }^{7}$ This section describes some key features of these data for our study, and we refer readers to Ghani et al. (2013a,b), Nataraj (2011) and Kathuria et al. (2010) for greater details and general descriptive statistics on these manufacturing surveys.

Our work mainly considers the portion of the Indian economy surveyed by the National Sample Survey Organisation (NSSO). The NSSO periodically collects information on a

\footnotetext{
${ }^{7}$ In all cases, the survey was undertaken over two fiscal years (e.g., the 1994 survey was conducted during 1994-1995), but we will only refer to the initial year for simplicity. We utilize the 1989 version of the NSSO survey to check for pre-trends in women's employment in manufacturing by state, but this dataset unfortunately lacks the key business ownership variables upon which we build our entrepreneurship metrics.
} 
representative sample of the unorganized manufacturing sector. A manufacturing establishment is considered part of the unorganized sector if it has fewer than ten employees and uses electricity. If the establishment does not use electricity, the threshold is 20 workers. As of 2005, the unorganized sector accounts for approximately 99\% of Indian manufacturing establishments, $80 \%$ of Indian manufacturing employment, and 16\% of Indian manufacturing output.

Establishments are surveyed by the NSSO with state and four-digit National Industry Classification (NIC) stratification. Using the provided sample weights, we construct populationlevel estimates of establishments and employment, and we aggregate the cross-sectional microdata to the state and three-digit NIC level. This allows observation of state-industry cells at three periods during which political reservations were implemented differentially by state. This time variation provides for our differences-in-differences identification strategy.

The outcome measures of business ownership and creation (as well as the control variables) are based on the number of observations in each state-industry cell multiplied by the sampling weight. In the estimations which use an employment-based measure of entrepreneurship, we consider the total employment at an establishment to consist of working owners plus any paid and unpaid employees.

We detect the gender of the business owner based on a survey field which captures details regarding the ownership of the establishment. The NSSO surveys since 1994 include questions which classify the ownership of each establishment among several types (1994 titles): proprietary (male), proprietary (female), partnership with members of the same household, partnership between members not of the same household, cooperative society, public sector, limited company (outside public sector), or other/unknown. We focus primarily on the establishments listed as either male proprietary or female proprietary, which constitute $98 \%$ of establishments in the unorganized manufacturing sector. The information captured in this field is an outcome of the survey and not a factor in the stratification design.

In our later analysis, we also investigate specifically household-based establishments by employing a survey question which captures details regarding premises of the establishment. The establishment premises can be listed as any of the following (1994 titles): no fixed premises, 
premises same as household's residence, and premises independent of household's residence. Household-based establishments are defined using the second group above. ${ }^{8}$

Our analysis primarily considers recent women entrepreneurs, who are a subset of women establishment owners. We identify entrepreneurs using a survey field which asks about the growth status of the enterprise over the past three years: expanding, stagnant, contracting, or operated for less than three years. Those owners who answer as having operated their business for less than three years constitute our subset of recent entrepreneurs. We also describe in the next section how the survey collects age information for older establishments.

It is important to note that the NSSO sampling frame is primarily built off India's periodic Economic Censuses, and is enumerated across households. The core sample is comprised of unregistered (unorganized) plants. Unorganized sector firms in India are not required to register or pay taxes, and thus the sampling of the NSSO does not depend upon these types of data. As we discuss later, this data collection and sampling approach provides confidence that the economic patterns we observe are real and not the artificial consequence of changes in reporting behavior (e.g., switching tax status). ${ }^{9}$

We supplement our investigation into women's labor market dynamics using data from the Annual Survey of Industries (ASI). The ASI provides microdata on the organized manufacturing sector of the economy, which is not covered by NSSO. The two surveys are designed to be perfect complements in joint coverage of the entire manufacturing sector. We use ASI surveys from the same fiscal years as the NSSO data described above to investigate

\footnotetext{
${ }^{8}$ The categories listed for the ownership and premises fields are taken from the 1994 survey instrument. Later surveys expanded the listed categories to include additional ownership categories that do not overlap with the primary male/female proprietary categories used in this work. There have been recent efforts to better measure and classify home-based work (Chen 2012), and it is possible that some household-based workers previously considered business owners may be reclassified as wage workers in future surveys. Adjustments during our sample period are very small, if present at all, and would apply uniformly to states in a way that would not bias a differences-indifferences strategy.

${ }^{9}$ The sampling frame for the NSSO is comprised of two frames: the list frame and the area frame. The list frame is used only among urban areas, and is comprised of approximately 8,000 larger unorganized manufacturing units on the basis of census data for manufacturing enterprises. These plants meet one of three detailed size criteria (available from the authors). All units in the list frame are surveyed, and these units are excluded from the list of enterprises in the area frame. The area frame is applied to both urban and rural areas. Village lists from the census form the frame for rural areas, and the frame for urban areas is taken from the latest Urban Frame Survey blocks. The ultimate stage units are households/unorganized-manufacturing enterprises in both areas, as available from the most recent economic census.
} 
employment of women in the organized sector. ASI surveys have a similar design ${ }^{10}$ and stratification as the NSSO surveys, and we construct population-level estimates of employment in the organized sector at the state-industry level similar to above. We capture separate men's and women's employment in the organized sector based on fields in the ASI reporting plant employment by gender. We also use the 1989 ASI to check for pre-trends in women's employment by state in the organized sector.

Unfortunately, ASI surveys do not collect the gender of the establishment owners, and so we can only examine ownership and entrepreneurship outcomes in the unorganized sector. Even within the unorganized sector, our results below emphasize household-based establishment entry rather than independent facilities. This pattern suggests that the lack of ownership data in the ASI is not a material concern as it is unlikely that we would observe heightened women's entrepreneurship in the organized sector.

Table 1 provides descriptive statistics on our sample. The first three columns provide aggregate establishment counts, employment, and output for each year across all of India. Since we have data on the timing of political reservation implementation for all states and territories in India, we do not restrict our sample geographically. These aggregates are broken down into organized- versus unorganized-sector contributions. For the unorganized sector, we further report women-owned establishments and then household- versus non-household-based establishments for women. Columns 4 and 5 describe the growth rate of each economic activity from 1994 to 2005, and Columns 6-8 provide shares relative to the total.

As noted earlier, the unorganized sector accounts for a large share of establishment counts and employment. Moreover, these shares are very persistent, as discussed further in Ghani et al. (2013c). Women-owned establishments in the unorganized sector account for a small share of total manufacturing activity: in 2005 , they represent $36 \%$ of establishments, $19 \%$ of employment, and $1 \%$ of output. Most of this activity is household based. For example, $90 \%$ of employment in women-owned establishments was in household-based operations in 2005.

While being a small share of total activity, women-owned establishments have experienced much more rapid growth during the 1994-2005 period than the manufacturing sector

\footnotetext{
${ }^{10}$ The ASI sampling frame is based on business registers rather than the Economic Census.
} 
as a whole. While manufacturing employment generally grew 17\% from 1994 to 2005, employment in women-owned establishments in the unorganized sector grew $138 \%$, roughly doubling the share of total activity accounted for by these establishments. As the second breakout for employment data highlights, this ownership growth is substantially stronger than even the employment growth for women in the unorganized sector, which expanded $26 \%$. Our study analyzes in part the extent to which political reservations for women can account for this strong performance on the ownership margin.

Among the major states, those with the highest share of new proprietary businesses in the unorganized sector owned by women in 1994 are Karnataka, Tamil Nadu, Andhra Pradesh, and Kerala. Those with the lowest share of female entrepreneurs are Uttar Pradesh, Haryana, Maharashtra, Madhya Pradesh, and Rajasthan. Similar patterns hold across states when comparing overall business ownership rates by gender. All but one state (Sikkim) saw an increase in the share of new businesses owned by women during the period we study.

Women's entrepreneurship and business ownership rates relative to men are highest among traditional and low-technology industries such as tobacco, paper, textiles, and wood products. These same industries comprise the industries in which most women-owned businesses are found in absolute terms. During our sample period, more than $90 \%$ of new female-owned businesses were found in 6 of 22 broad two-digit industries: textiles, tobacco, wood products, food products, furniture, and chemical products. At the two-digit level, nine industries saw an increase in the share of new businesses created by women between 1994 and 2005, with the largest increases for female entrepreneurship being among these traditional industries.

Our final data source is comprised of six rounds of the NSSO's household-level Employment-Unemployment survey conducted from 1983 to 2009. The sampling frame for these surveys captures a representative sample of the Indian population, and aggregate figures are calculated based on the sampling weights provided with the data. The surveys lack the ownership fields required to study entrepreneurship, but they do contain information that allows us to model women's employment in unorganized manufacturing. In the typical survey, 3\%-4\% of women are employed in manufacturing, with over $60 \%$ of women listing domestic activities. We specifically use the designation of the respondent's employer as an Own Account Enterprise (OAE) to proxy for the unorganized sector. These surveys aid our empirical work in three ways: 
1) providing a second set of estimations regarding women's employment in manufacturing during our core sample period, 2) allowing us to assess whether pre-trends exist with respect to this employment, and 3) providing us insight about whether the changes that we observe with respect to the manufacturing sector appear to be pulling from other sectors.

\section{Analysis of Reform Timing and Pre-Existing Entrepreneurship}

Iyer et al. (2012) introduce the technique of using state-level variation in the timing of effective implementation of the Indian reservations. Iyer et al. (2012) further provide evidence that the effects that they document of the reservations on state-level reporting of crime against women follow after the implementations with timing that indicates the reservations were implemented in a manner plausibly exogenous to their outcome of interest. This section provides similar evidence with respect to our measures of women-owned establishments.

Figure 2 first analyzes initial economic conditions of states in 1994 and the order in which states implemented the reservations. The upper left panel starts with a cross-sectional plot of the log count of women-owned establishments per capita in the state on the vertical axis against the year of reservation implementation by state on the horizontal axis. Bubble size indicates the size of the state using log population. States that never adopt the reforms are excluded from this analysis and the similar one for Figure 3.

The trend line in this panel is flat, indicating that the timing of implementation was not linked to the initial prevalence of women-owned manufacturing establishments in the state. The same holds in the lower left panel, which considers the shares of unorganized manufacturing establishments that are women owned. The two right panels provide similar graphs of initial women's entrepreneurship for manufacturing in the states using new establishments from the NSSO. Again, the relationship is very limited, if any exists at all. The t-statistics for all trend lines are less than one with robust standard errors.

As Manipur is a persistent outlier on these graphs, we cap its value at the second highest state's value for visual ease. Given Manipur's very small size and mid-point timing for implementation of political reservations, this treatment does not affect trend lines calculated. Likewise, the very small state of Arunachal Pradesh shows very low initial activity by women in 
manufacturing and very late implementation. We have confirmed that that all results in the paper hold if excluding Arunachal Pradesh.

We conduct much of our empirical analysis at the state-industry level. Figure 3 repeats Figure 2 at this disaggregated level. The horizontal axis continues to be the timing of each state's implementation, while the vertical axis documents pre-existing women's entrepreneurship on a per-worker basis or as a share of activity. For the left two panels on women's ownership shares, there is again little evidence of a relationship to the sequence of state implementations. The added data variation allows for more precise trend lines, but we continue to reject the hypothesis that the trend lines are different from zero. For the right two panels on new establishments, we do see more evidence that later-adopting states have lower entrepreneurship when each industry is treated separately. These trend lines are statistically significant. On the whole, however, they are very small in size relative to the magnitudes that we will estimate due to the reforms.

As a complement to these levels of activity and shares in 1994, we would ideally be able to examine changes in women's entrepreneurship and ownership rates over the period immediately before 1994 to check whether there are pre-trends in the data that correlate with the relative timing of state implementations. We are unfortunately not able to conduct this analysis directly because 1994 is the first survey to collect gender-differentiated ownership information. We are, however, able to achieve the spirit of this check for pre-trends in two complementary ways.

First, the 1994 NSSO data include the ages of plants beyond the 0-3 years-old group that we use to define entrepreneurship. ${ }^{11}$ One approach to testing for pre-trends is to look at the age structure of women-owned businesses in 1994 by the dates at which states will implement the elections. If there are substantial pre-trends for early adopters in the years immediately before 1994, one might anticipate seeing an abnormal profile for early adopters indicative of a pre-trend in entry levels.

Figure 4 shows that early and late adopters of the political reform have similar plant age profiles for women-owned businesses overall. In each panel, the horizontal axis provides seven age groups for establishments: 0-1 years, 2-3 years, 4-5 years, 6-7 years, 8-9 years, 10-25 years,

\footnotetext{
${ }^{11}$ This age detail was dropped from the questionnaire in later rounds of the survey.
} 
and $26+$ years. ${ }^{12}$ We divide our sample into states implementing reservations before 1996, states implementing reservations in 1996 and afterwards, and states never implementing reservations. There are equivalent numbers of states in these groups at 11, 11, and 10 states, respectively.

Panels A and B provide the cumulative distribution function (CDF) for female- and maleowned establishments across the establishment age categories, respectively. As a whole, the differences between the three groups are quite limited. Moreover, what differences do exist do not display a particular ordering that would cause concern-states that implement reforms prior to 1996 are positioned between the states that will later adopt the reforms versus those that do not adopt the set-asides at all during our sample period.

Panel $\mathrm{C}$ next documents within each establishment age category the share of plants that are owned by women in 1994 for the three groups. The overall penetration of women-owned businesses is higher in 1994 for younger establishments, peaking with the group that is 4-5 years old. This is also visible in Panels A and B by noticing the upward shift at the lower end of the distribution for the women-owned CDF compared to the male-owned CDF. All three groups display this property of a larger relative presence for women-owned business among young establishments, although the distribution is smoother for the never-adopting states. Panel D shows this uniformity even more sharply by dividing these shares by the average of each group across all age buckets (with the overall averages having been the subject of Figures 2 and 3 ). In this normalized format, there is an extremely close correspondence between states adopting before 1996 and those adopting 1996 and afterwards. A Pearson chi-squared test for Panel D does not reject the null hypothesis that the states adopting before 1996 and those adopting 1996 and afterwards are similar.

Overall, Figure 4 suggests that the age structure is quite similar for establishments across different groups of states that will be adopting the reforms at different times. Examining the age distribution for evidence of pre-trends is not a perfect test, as it could be that new entrants go out of business so rapidly as to not influence the medium-run age distributions of plants. Likewise, 1994 is of differing distances from the reform dates for states, which may limit the potential to detect pre-trends. While acknowledging these limitations, it is reassuring to note that the sizes of

\footnotetext{
${ }^{12}$ Appendix Figure 1 shows an alternative grouping of 0-3, 4-6, 7-9, 10-15, 16-25, and 26+ years.
} 
the 4-5 and 6-7 year-old groups are as large as the 0-1 and 2-3 year-old groups (in absolute terms and relative to men). This indicates that tremendous churn at the entry margin is unlikely to be occurring, providing evidence against pre-trends that are influencing the timing of elections. Based upon Figure 4's deviations for never-adopting states, we will specifically test below that our results are robust to this group's inclusion or exclusion.

As a second approach, we look for pre-trends in women's involvement in manufacturing on dimensions other than entrepreneurship. We can do this with respect to women's raw employment in manufacturing and their share of manufacturing employment in three ways: the unorganized sector through the 1989 and 1994 NSSO surveys, the organized sector through the 1989 and 1994 ASI surveys, and the household surveys from 1987 and 1993 . Appendix Table 2 reports an analysis similar to that in Figures 2 and 3.

We examine the degree to which the log growth in women's employment by state or state-industry in the years preceding our sample period correlates with future election timing. These estimations find no evidence that changes in women's employments in manufacturing in the pre-period predict the ordering of implementations across states. These tests are also admittedly imperfect, as we do not later observe a strong response on this margin, and we unfortunately cannot measure the entry margin similarly. Nonetheless, the combination of these tests with those of the 1994 establishment age distributions do provide substantial support to our identification assumption that the election timings are exogenous. After we introduce our estimation strategy, we further examine dynamic estimations that also show the responses in women's entrepreneurship follow the reforms in a timing that is consistent with the reservations causing the increased entry rates.

\section{Empirical Analysis}

This section provides our core empirical results. We begin with a broad analysis of the impact for women in manufacturing that includes wage employment and establishment ownership. After observing the concentrated impact on entrepreneurship, we conduct a focused analysis on the industry differences and household-basis of the entrepreneurship finding. We close with an analysis of district pairs along state borders. The next section will test several hypotheses about channels through which this effect operates. 


\section{State-Level Patterns}

Table 2 provides a broad analysis of women's role in the manufacturing sector following the implementation of political reservations. We have 3606 observations that come from 32 states (pre-2001 definitions) and 59 three-digit NIC industries. ${ }^{13}$ We weight regressions by the log initial employment in the state-industry and cluster standard errors by state. Outcome variables are in logs. As we encounter some zero-valued cells, we add one to all outcome variables before taking logs. This maintains a consistent sample over outcomes, and it is not an important factor given our weights of initial employment in state-industries.

Following the empirical approach developed by Iyer et al. (2012), our primary regressor is similar to an indicator variable that takes a value of zero before the implementations and a value of one afterwards. We additionally take into account the initial conditions of the two states with earlier, partial set-asides by assigning those states an initial value equal to their reserved share compared to the mandated level after the Amendments. This approach captures that the changes caused by the Amendments in these states were smaller than the discontinuities in other states that did not have prior set-asides. ${ }^{14}$

We conduct our regressions at the state-industry-year level to allow for an easy segue to the industry differences that we later study. This approach also allows us to control directly for industrial composition by state and changes in women-owned establishment activity that would be predicted by secular trends in industries nationally. We include in our estimations a vector of state-industry fixed effects and a vector of industry-year fixed effects. State-industry fixed effects remove aggregate levels differences across our sample in terms of the outcome variables,

${ }^{13}$ The total number of possible cells, in this case, would be 5,664 from interacting 32 states with 59 industries and 3 time periods. This theoretical count is reduced to 3,606 unique state-industry-year cells due to a number of state-industry cells not reporting any data in certain years. Nearly all of the remaining state-industry cells (95\%) have a full panel among the final 3,606 observations.

${ }^{14}$ Specifically, rather than code these two states as 0 and 1 before and after the reforms, we code them as 0.758 before the reforms and 1 after the reforms. The 0.758 comes from calculating the share of the overall reservations that have already been implemented - that is, $0.758=25 \% / 33 \%$. This approach takes into account that these states receive meaningful additional reform from the Amendments, but that they are already three-quarters of the way to the mandated level compared to their neighbors at the start of the period. Our results are robust to alternative approaches as noted below. 
focusing on within-cell changes with the implementation of political reservations. Industry-year fixed effects control for common patterns across states for each industry.

Outcome variables are indicated by column headers. Panel A models an indicator variable for a state-year observation where political reservations have been implemented in the state. Panel B includes an additional control variable that is the male-owned establishment analogue specific to the outcome variable studied. Thus, the dependent variable in the first column is the log count of new women-owned establishments in the unorganized sector measured by state-industry-year, and the additional regressor is the log count of new male-owned establishments in the unorganized sector in the same state-industry-year. This additional control provides a very powerful test by quantifying the relationship of reservations and women-owned establishments over-and-above contemporaneous male-owned business activity.

The results in Table 2 have a mixed message. On one hand, Columns 1 and 2 show a solid connection between the implementation of political reservations and women's entrepreneurship. The elasticities suggest a growth in new women-owned establishments and associated employment of approximately $40 \%$ after political reservations were implemented. New women-owned establishments account for on average $15 \%$ of all women-owned establishments. In Column 3, this growth in entry is associated with a positive response in total counts of women-owned establishments, but this response is imprecisely estimated. This smaller aggregate response may be due to the relatively short time frame for these changes to accrue; it may also indicate that some of the induced entry is short-lived.

Column 4 considers the log employment of women overall in manufacturing for the stateindustry, and Columns 5-7 separately consider employment in male-owned unorganized establishments, female-owned unorganized establishments, and the organized sector. While point estimates tend to be positive, there is no measurable evidence that political reservations increased women's employment in manufacturing. Thus, the implementation of political reservations in India connects to heightened entry of women-owned establishments but not to increased employment generally of women in manufacturing. ${ }^{15}$ From here on, we report exclusively the

\footnotetext{
${ }^{15}$ We confirm this limited employment response for women in manufacturing using the NSSO Employment-Unemployment survey stretching from 1983 to 2009. The estimates in the formats of Panels A and B of Table 2 would be 0.088 (0.353) and 0.089 (0.352), respectively, quite similar to Column 6.
} 
entrepreneurship findings (excepting for the border analysis) as this null finding for wage work generally holds in the additional tests below.

Table 3 uses this same framework to consider several segments of the unorganized entry response. The first column repeats the total entry response for women-owned businesses from Column 2 of Table 2. In Columns 2 and 3, we separately estimate the log growth in new womenowned establishments that are household based versus those opened in separate facilities. As the industry-year effects can adjust across the columns, the coefficient estimates do not necessarily bracket the total effect. This segmenting suggests that the entry is especially concentrated in household-based businesses. Columns 4 and 5 likewise highlight that the entry is higher among smaller establishments. This intriguing heterogeneity that favors small and household-based businesses will be expanded upon shortly when considering traits of industries. The final two columns show that entry is higher among businesses that do not rely on external financing, which we return to when discussing channels that promote the heightened entry rates in Section 6 .

Having noted the concentrated entry among small and household-based establishments, it is very intriguing to return to Table 1's descriptive tabulations. One striking feature of these tabulations not noted earlier is that the growth in women-owned establishments (4.1 million) is numerically more than the growth of women engaged in manufacturing (2.4 million). The latter measure includes business owners, so the aggregate traits strongly suggest women are switching from wage work into business ownership within the manufacturing sector itself. While crosssectional data cannot verify this directly, this switching would be very consistent with the small scale nature of the entry observed and reflective of the path of many entrepreneurs to start businesses in sectors where they were previously employed. At the aggregate level, this observation also connects to a sharp growth in women being employed in women-owned firms. Whereas $31 \%$ of women employed in the unorganized manufacturing sector in 1994 were employed in women-owned businesses, this share is $62 \%$ in 2005 . This shift is so strong that the share of female employees in women-owned firms increases from $86 \%$ to $92 \%$ across the period, 
as a $250 \%$ increase in women employed in women-owned plants (including owners) swamps an otherwise robust $40 \%$ increase in men employed in women-owned plants. ${ }^{16}$

\section{Dynamics Patterns of Entry and State-Level Election Timing}

Figure 5 provides a dynamic analysis of the entrepreneurship patterns to see if they possess a timing that links them to the implementation of political reservations. The estimations continue with the estimation approach of Table 2, but we introduce four indicator variables for the timing of the elections: 1-3 years before the state's elections, 0-1 years after the elections, 2-4 years after the elections, and 5+ years after the elections. Coefficients on these variables are relative to the period four or more years before the state's elections and non-adopting states. The solid lines are the coefficient estimates and the dashed lines give the $90 \%$ confidence bands. The dependent variable in Panel A is the log count of new women-owned businesses by state-industry-year; the dependent variable in Panel B is similarly defined for male-owned entrants. Estimations cluster standard errors at the state level and include state-industry and industry-year fixed effects. Appendix Table 3 reports the base estimates graphed in Figure 5.

The coefficient pattern for women-owned businesses is encouraging for our estimation design. There is no evidence of abnormal patterns for states in the 1-3 years before the elections were held, and the entry increase remains slight in the year of the political reform or immediately afterwards. This null result connects to the lack of pre-trends noted in the prior section, and it extends that earlier work to look specifically at pre-activity immediately before each state's elections (rather than, for example, the trends over states from 1989 to 1994).

Thereafter, we observe a heightened entry rate for 2-4 and 5+ years after the reform. This entry rate is statistically significant for the 2-4 year period and falls just short of conventional significance levels for $5+$ years. The lower panel shows no response for male-owned entrants other than a dip in pre-period. While our three data surveys do not have sufficient power to estimate year-by-year interactions with state-level clustering of standard errors, these estimates

\footnotetext{
${ }^{16}$ The share of male employees in male-owned firms is stable at $97 \%$ during the period. This extreme and growing segregation of the employment bases by the gender of business owner is a particularly important topic for future research.
} 
provide some supportive evidence that the timing of these entry patterns is consistent with the reserved election of the female political leaders. ${ }^{17}$

\section{Industry Variation and Household-Based Businesses}

To help understand this entrepreneurship response, Table 4 quantifies the industry traits associated with greater establishment entry rates. For all columns in Table 4, the outcome variable is the log count of new women-owned establishments in the state-industry-year. The column headers of Table 4 indicate various industry traits that we measure at the national level in 1994 by industry. The key explanatory variable is an interaction of the implementation of statelevel political reservations with the indicated industry trait.

By tapping into industry heterogeneity, we can provide further structure to our estimation framework by including state-year fixed effects. These fixed effects control for the aggregate changes in activity by state in each year, including the main effects for state implementation that we quantified in Table 2. Thus, we only identify effects in Table 4 by looking at whether women-owned establishment entry in industries with a given trait responded more compared to other industries in the same state. We cluster standard errors by state-industry to reflect the fact that our estimates are exploiting this heterogeneity across industries within states.

Column 1 shows that the state-level entry response to the political reservations was stronger in industries where women-owned establishments represented a larger share of establishments nationally in 1994. Appendix Table 4 documents these shares at the two-digit industry level across manufacturing industries, which range from over $40 \%$ in chemical products and tobacco products to less than 5\% in over half of the two-digit industries. Estimations exploit variation at the three-digit NIC level that is similarly large. The increase in entry rates for

\footnotetext{
${ }^{17}$ Appendix Figure 2 shows our raw data and provides some evidence on these reservations using major states within India. For each state and survey, we calculate the ratio of entering female-owned establishments in the unorganized sector compared to male-owned entrants. We then plot this ratio across years, with each state centered so that the vertical black line at zero represents the year when the state implemented the reservations. While some deviations exist, in most states the ratio is stable prior to reservation implementation, and then the ratio increases after implementation. Figure 5 quantifies these responses more precisely, but the raw data depiction provides additional assurance that the entrepreneurship response is broad-based and not the product of a few outlier states.
} 
women-owned establishments is 3\% higher for each $10 \%$ increase in the extent to which women have traditionally owned establishments in the sector.

Column 2 finds heightened entry in industries that traditionally centered on householdbased establishments, and Column 3 connects the first two results with those noted in Table 3 by modeling the intensity of women-owned household-based establishments by industry in 1994 . For every $10 \%$ increase in the degree to which an industry nationally is populated by womenowned businesses based in the household, the entry response is 4\% higher. Columns 4-6 show the corollary to Columns 1-3 that the heightened women's entrepreneurship is weaker in industries with larger average establishment sizes, value-added per worker, and fixed capital intensity. These negative patterns continue to hold when calculating these three industry traits using only female-owned establishments in 1994.

The skewness of the traditional women-ownership shares raises concern that the strong patterns in Columns 1-3 may be driven by just a few outlier industries. Appendix Table 5 tests this concern by considering different formats for the industry interaction, building upon the estimations in Column 3 of Table 4. We report estimations that utilized the raw shares of establishments in industries owned by women operating out of households, these shares expressed in unit standard deviation, and indicator variables for terciles of share intensity. Similar results are found in these variants, and the indicator variable approach in particular suggests that the most important difference occurs between the bottom tercile of ownership (the excluded group) and the upper two terciles.

Table 5 tests other variations on these key estimations. Column 2 shows very similar results when using the Iyer et al. (2012) coding strategy that does not consider fractional values for the two states that have partial early adoption. Column 3 likewise shows similar results when excluding these two states entirely. Column 4 shows marginally stronger results when excluding non-adopting states. ${ }^{18}$ Column 5 shows robustness to excluding the two industry groups with the

\footnotetext{
${ }^{18}$ We also examine the possibility that the timing of elections was chosen endogenously depending upon the desire of the state to implement the reforms. For 21 states, we are able to reasonably ascertain the year of the first pre-scheduled election after the Act passed. This group shows an OLS coefficient of $0.343(0.139)++$. When using the pre-scheduled election as an instrument for the actual election, we achieve a second-stage elasticity of $0.402(0.176)+$. We do not reject the null hypothesis that OLS and IV are the same. These results and related reduced-form exercises suggest that this endogenous scheduling concern is not critical, but we remain overall cautious about strong claims in this dimension. First, we found conflicting reports regarding the years of pre-1993
} 
highest women's ownership shares in 1994. This exclusion is performed at the two-digit level to remove industries related to chemical products and tobacco products. Column 6 shows precision at the $10 \%$ level continues to hold when instead clustering standard errors at the state level. Column 7 shows very similar results when excluding the state-year fixed effects and instead controlling again for the main effects of the political reforms.

\section{State Border Discontinuity Analysis}

Before turning to an evaluation of the mechanisms that lie behind these patterns, we confirm the importance of the political set-asides in a novel manner using district pairs along state borders.

One question that we have attempted to address throughout this study is whether early-adopting states were growing in systematically different ways with respect to women's participation and entrepreneurship than later adopters that led them to endogenously adopt first. A second concern that we have been battling with is the possibility that states implemented other changes at the same time as they implemented the political reservations. We worked to alleviate the first concern with the exercises in Section 4 and our dynamic specifications, and we relied on stringent fixed effects, industry variations, and male analogues for outcome variables to get after the second set of concerns.

Many papers in literature exploit another identification technique by looking at which villages receive randomized assignments for women set-asides. Even in a cross-sectional format, this randomization is very attractive due to how it addresses the above concerns. Unfortunately, we have not identified any data sources that combine village- or panchayat-level information on our outcomes of interest and these reservations. The most disaggregated spatial identifier in the Indian data is instead the district. ${ }^{19}$ This level does not provide us the appropriate randomization since the randomization is undertaken across villages within each district, and thus each district within a state is receiving a similar treatment.

elections and terms of office for some of the states, necessitating judgment calls in these cases. Second, the 21 states for which we could obtain data may not be representative of the full set of states.

${ }^{19}$ Districts are administrative subdivisions of Indian states or territories that provide meaningful local economic conditions. The average district size is around 5,500 square kilometers - roughly twice the size of a U.S. county—and there is substantial variability in district size (standard deviation of $\sim 5,500$ ). 
We can, however, replicate the spirit of the village-level tests by looking at district pairs along state borders. The idea is to take two adjacent districts, one located in state $\mathrm{A}$ and the second in state B, and look at their relative rates of women's entrepreneurship or manufacturing employment in 2005. If state A adopted the reservations well before state B, we would expect the women's outcome variables in state A to be higher. Moreover, because state A borders other states, this gap in implementation can be different for other districts in state A and their adjacent pairs in states $\mathrm{C}$ or $\mathrm{D}$. This approach thus achieves some of the randomization and localization that the village-level studies capture, despite the fact that reservations for the districts in state A are all implemented at the same time and across the same share of panchayats.

We identify 352 unique, adjacent district pairs that are located in neighboring states. We alphabetically assign districts the roles of District 1 and District 2, and our specification below does not depend upon this assignment. We then calculate the log ratio in 2005 of the women's outcomes in the two districts - for example, $\ln$ ([new women-owned establishments, district 1] / [new women-owned establishments, district 2]). We then regress these outcomes on the difference in cumulative exposure to reservations as of 2005: [years since implementation, district 1] - [years since implementation, district 2]). We also include fixed effects for each state that makes up the district pair and a control for what the ratio being studied as the dependent variable was in 1994.

A positive coefficient connects longer relative exposure to the political set-asides with a greater gap in women's outcomes along the border in 2005, controlling for what the gap was in 1994. As noted in the introduction, this test is not a complete resolution of all identification concerns, however. Most importantly, if other policies are implemented in a consistent pattern across states at the same time as the political reservations, we will not be able to separate these effects. We cluster standard errors by pairs of states to reflect the common variation being exploited when a state pair has multiple adjacent district pairs. We weight estimations by the interaction of log initial employment in the two districts. ${ }^{20}$

\footnotetext{
${ }^{20}$ We drop the industry dimension for this exercise to have well-populated cells, given that the surveys are undertaken with state-industry stratification. We also focus on just the unorganized sector given the greater difficulty for aligning ASI district codes for 1994.
} 
Table 6 presents the estimations in a format similar to Table 2. Panel A includes state fixed effects, the 1994 ratio control, and the focal measure of gap years in implementation duration. Even more powerfully, Panel B also controls for the ratio of the outcome variable in 2005 using male-owned establishments in the district pair. These estimations again link higher women's participation in 2005 to how long the reservations have been in place, even in the presence of the male-owned plant controls. They provide stronger evidence that women's employment increases in manufacturing than our earlier approaches, but this remains tentative overall. Most importantly, they again confirm the particularly heightened nature of women's entrepreneurship and new business ownership that is closely timed with the political reservations, subject to the identification limitations noted above.

\section{Discussion of Mechanisms}

Section 5 finds substantial growth in women's entrepreneurship after the state-level implementations of political reservations for women leaders. This growth was concentrated in industries where women have traditionally owned establishments and in a form that favored household-based enterprises. This section discusses potential mechanisms that could be behind these results.

Before considering these channels, it is helpful to depict a little more closely the types of entrants that we are observing and the extent to which they may be drawn from one activity versus another. This discussion also sheds light on whether these patterns of entrepreneurship in the unorganized sector represent advancements for women. This notion has been somewhat implicitly held through the discussions, but it should be delineated more carefully. Recent work stresses the potential heterogeneity of businesses and opportunities in the unorganized sector and how that can influence policy perspectives (e.g., Gunther and Launov 2012).

Table 7 compares women-owned business in the unorganized sector to those owned by men. In Panel A, we present the average values for five metrics over the 1994-2005 period by gender and their ratio. Women-owned businesses have about $18 \%$ of the output (measured as the value of total establishment shipments or sales) of their male counterparts, $60 \%$ of the employment, and $32 \%$ of the asset base. It is clear that women-owned businesses are typically smaller. The last two columns further show that they are less productive and capital intensive on 
a per-employee basis. Panel B shows these ratios over time. The ratios for shipments and employment have declined from their 1994 values to 2005, while fixed assets have been stable. The labor productivity measure has also declined. Capital intensity improved, but only because average employment declined.

The general rapid expansion in business ownership for women during the 1994 to 2005 period has been at a very small business size that widened the gap between women- and maleowned enterprises in the unorganized sector. In 2005, this entry margin was perhaps a third of the size of the typical unorganized sector business. Our estimations and their focus on small, household-based businesses link well with this margin. Moreover, this reinforces the need for channels that support this entry to operate at the very small scale. ${ }^{21}$

In terms of mechanisms, the online appendix provides evidence on three potential channels that we can directly test - reporting bias, access to government contracts and business, and access to finance. We are cautious about emphasizing any particular channel given data constraints and that several channels may be working simultaneously. Nonetheless, these extensions help articulate how the political reforms may have had an impact on local women entrepreneurs. While financing appears to be the strongest of these three channels, we also find that external finance cannot explain the majority of the increased female entrepreneurship that we observe. It is clear that more women-owned establishments with financial backing enter after the reforms, but this increase is only part of a general expansion for female entrepreneurship, rather than the sole driver.

What else could play a role? While we cannot offer a definitive explanation, our results are consistent with two likely hypotheses that we cannot directly test-provision of local infrastructure and inspiration for women entrepreneurs. To understand these candidates, it is helpful to first discuss why we believe the differences in entry rates across industries particularly favored those industries where women-owned businesses previously existed. This feature is likely a reflection of a more general pattern for female entrepreneurs to select sectors where existing women-owned businesses are strong due to local networks (e.g., Ghani et al. 2013a).

${ }^{21}$ Appendix Table 6 provides additional tabulations that are consistent with the induced entry from outside manufacturing that we are observing to have come from unpaid domestic work or from shifts away from agriculture/mining. 
The household scale of these new establishments following the political reforms is a more novel pattern and follows partly from the fact that most women-owned establishments in unorganized manufacturing are household based.

This related work about the specificity of local industrial networks among women-owned businesses is important for understanding the type of local stimulus we should be considering. Specifically, the stimulus following the elections can be neutral towards industries in its form and still match our cross-industry differences. That is, the stimulus does not necessarily need to target industries favored by women-owned businesses. In fact, the more neutral the orientation of the stimulus, the more likely we are to observe the industry patterns exhibited, with the added twist in this case that industries with a strong household-based nature are particularly affected. This is because a neutral stimulus can prompt entry rates that build upon and extend the existing foundation of women-owned businesses.

So what could be the local, neutral factor? We have two candidate explanations, neither of which we can definitely confirm. The first explanation descends directly from the celebrated studies that began this literature about how reserved leadership positions can influence the allocation of local resources (e.g., Pande 2003, Besley et al. 2004, Chattopadhyay and Duflo 2004a,b). This work highlights how the Indian political reservations stimulated greater provision of funds towards infrastructure and public goods favored by the minority group and/or greater access to existing infrastructure. This heightened provision of infrastructure and public goods specific to women could have lowered the cost of entrepreneurship for women, resulting in higher entry rates. To this end, a very consistent finding in studies of Indian entrepreneurship generally (i.e., male and female combined) is the important role of local infrastructure (Ghani et al. 2013a,b, Mukim 2011). Thus, a greater general provision of infrastructure and public goods towards women can match both the entry response and the cross-industry differences. It is important to note that this provision would need to have assisted women disproportionately compared to men in order for us to have observed entry rates in excess of the baseline responses of male-owned businesses. Overall the village-level evidence developed in the prior studies would be consistent with our work.

A second candidate explanation is that the political reservations inspired women to start their own businesses. The striking findings of Beaman et al. (2012) are that female leadership 
reservations in local areas through the set-aside programs increased the desire of women for more educational attainment and stronger careers. It is possible that our results are a reflection of these greater aspirations. An inspiration stimulus would again be mostly neutral, and thus could align well with the industry patterns we observe. A strong factor favoring this channel is that an inspiration account would also naturally connect to the smaller-scale nature of our entry patterns given that the inspiration stimulus is plausibly most likely to influence entry choices at the smaller end of establishment sizes (i.e., those who would not have otherwise entered without the inspiration are likely to be those starting smaller firms than those who would enter regardless).

While both of these hypotheses are appealing, we are cautious to note that we cannot differentiate between them. We likewise cannot completely separate them from other state-year factors that could be tied to the reservations (e.g., women-oriented policies promoted by local governments). Our comparative advantage in this project compared to the emerging literature stream overall is that we are able to quantify the economic patterns for the full Indian manufacturing sector. Administrative datasets, however, have natural limits for measuring subtler factors like women-oriented public goods or inspiration. We hope to encourage future research at the village level to pick up on these entrepreneurship dimensions. To date, we are not aware of any village-level studies that have collected information about women's entrepreneurship, and our study highlights the high potential return for doing so.

\section{Conclusions}

The implementation of political reservations had strong effects for empowering women in India in many spheres. While we do not see much evidence that this increased women's employment in manufacturing, we do identify that women are more likely to start new establishments in the unorganized sector after the reforms. This growth in entrepreneurship was concentrated in industries that women have traditionally been active in and at the household-establishment scale.

This study provides among the first evidence of how political reservations can affect economic outcomes for women. This linkage is important given that many long-term gains and entrenchment of the empowerment benefits from political reservations can be aided by better economic opportunities that grow in parallel with political voice. These linkages may also affect economies in other ways, given the rise in women's participation. In related work for example, 
Ghani et al. (2013c) find evidence that growing women's entrepreneurship can support the persistence of the informal sector in which many of these business start. We hope that future work considers other economic outcomes and evidence from outside of India on these important issues.

\section{References}

Amin, Mohammad, “Gender and Informality”, World Bank Enterprise Note 16 (2010).

Beaman, Lori, Raghabendra Chattopadhyay, Esther Duflo, Rohini Pande, and Petia Topalova, "Powerful Women: Does Exposure Reduce Bias?”, Quarterly Journal of Economics 124:4 (2009), 14971540 .

Beaman, Lori, Raghabendra Chattopadhyay, Esther Duflo, Rohini Pande, and Petia Topalova, "Female Leadership Raises Aspirations and Educational Attainment for Girls: A Policy Experiment in India”, Science 335 (2012), 582-586.

Beaman, Lori, Esther Duflo, Rohini Pande, and Petia Topalova, "Political Reservation and Substantive Representation: Evidence from Indian Village Councils", India Policy Forum (2010), 159-201.

Besley, Timothy, Rohini Pande, Lupin Rahman, and Vijayendra Rao, "The Politics of Public Goods Provision: Evidence from Indian Local Government", Journal of the European Economic Association 2:2-3 (2004), 416-426.

Bruhn, Miriam, "Female-Owned Firms in Latin America: Characteristics, Performance, and Obstacles to Growth", Working Paper (2009).

Chattopadhyay, Raghabendra, and Esther Duflo, "The Impact of Reservation in the Panchayati Raj: Evidence from a Nationwide Randomized Experiment", Economic and Political Weekly 39:9 (2004a), 979-986.

Chattopadhyay, Raghabendra, and Esther Duflo, "Women as Policy Makers: Evidence from a Randomized Policy Experiment in India", Econometrica 72:5 (2004b), 1409-1443.

Chen, Martha Alter, and G. Raveendran, "Urban Employment In India: Recent Trends And Patterns", The Journal of Applied Economic Research 6:2 (2012), 159-179.

Clots-Figueras, Irma, "Women in Politics: Evidence from the Indian States", Journal of Public Economics 95:7-8 (2011), 664-690.

Deininger, Klaus, Songqing Jin, Hari Nagarajan, and Xia Fang, "Does Female Reservation Affect Longterm Political Outcomes? Evidence from Rural India", World Bank Working Paper (2011).

Dhaliwal, Spinder, "Asian Female Entrepreneurs and Women in Business - an Exploratory Study", Enterprise and Innovation Management Studies 1:2 (2000), 207-216. 
Duflo, Esther, "Why Political Reservations?" Journal of the European Economic Association 3:2-3 (2005), 668-678.

Duflo, Esther, “Women Empowerment and Development”, NBER Working Paper 17702 (2011).

Duflo, Esther, and Petia Topalova, "Unappreciated Service: Performance, Perceptions, and Women Leaders in India”, Working Paper (2004).

Estrin, Saul, and Tomasz Mickiewicz, "Institutions and Female Entrepreneurship", Small Business Economics 37 (2011), 397-415.

Field, Erica, Seema Jayachandran, and Rohini Pande, "Do Traditional Institutions Constrain Female Entrepreneurship? A Field Experiment on Business Training in India", American Economic Review Papers and Proceedings 100 (2010).

Ghani, Ejaz, William Kerr, and Stephen D. O'Connell, "Local Industrial Structures and Female Entrepreneurship in India”, Journal of Economic Geography 13:6 (2013a), 929-964.

Ghani, Ejaz, William Kerr, and Stephen D. O'Connell, "Spatial Determinants of Entrepreneurship in India", Regional Studies (2013b), forthcoming.

Ghani, Ejaz, William Kerr, and Stephen D. O'Connell, "Female Business Ownership and Informal Sector Persistence", World Bank Working Paper 6612 (2013c).

Ghani, Ejaz, Anandi Mani, and Stephen D. O'Connell, "Can Political Empowerment Help Economic Empowerment? Women Leaders and Female Labor Force Participation in India”, World Bank mimeo (2013).

Ghosh, Piyali, and Reena Cheruvalath, "Indian Female Entrepreneurs as Catalysts for Economic Growth and Development", The International Journal of Entrepreneurship and Innovation 8:2 (2007), 139-148.

Government of India, Study on EWRs in Panchayati Raj Institutions. Ministry of Panchayati Raj (2008).

Gunther, Isabel, and Andrey Launov, "Informal Employment in Developing Countries: Opportunity or Last Resort?”, Journal of Development Economics 97:1 (2012), 88-98.

Hausmann, Ricardo, Laura Tyson, and Saadia Zahidi, The Global Gender Gap Report 2011 (Geneva, Switzerland: World Economic Forum, 2011).

Hoff, Karla, and Joseph Stiglitz, "Equilibrium Fictions: A Cognitive Approach to Societal Rigidity", American Economic Review Papers \& Proceedings 100 (2010), 141-146.

Iyer, Lakshmi, Anandi Mani, Prachi Mishra, and Petia Topalova, "The Power of Political Voice: Women's Political Representation and Crime in India", American Economic Journal: Applied Economics 4:4 (2012), 165-193.

Jensen, Robert, "Economic Opportunities and Gender Differences in Human Capital: Experimental Evidence from India”, NBER Working Paper 16021 (2010). 
Kathuria, Vinish, Seethamma Natarajan, Rajesh Raj, and Kunal Sen, "Organized versus Unorganized Manufacturing Performance in India in the Post-Reform Period", MPRA Working Paper No. 20317 (2010).

Kobeissi, Nada, "Gender Factors and Female Entrepreneurship: International Evidence and Policy Implications", Journal of International Entrepreneurship 8:1 (2010), 1-35.

Klapper, Leora, and Simon Parker, "Gender and Business Environment for New Firm Creation", World Bank Research Observer (2011).

Mammen, Kristin, and Christina Paxson, "Women's Work and Economic Development", Journal of Economic Perspectives 14:4 (2000), 141-164.

Mathew, George, Status of Panchayati Raj in the States of India, 1994 (New Delhi, India: Institute of Social Sciences. Concept Pub. Co., 1995).

Mathew, George, Status of Panchayati Raj in the States and Union Territories of India (New Delhi, India: Institute of Social Sciences. Concept Pub. Co., 2000).

Minniti, Maria, "Female Entrepreneurship and Economic Activity", European Journal of Development Research 22 (2010), 294-312.

Minniti, Maria, "Gender Issues in Entrepreneurship", Foundations and Trends in Entrepreneurship 5:7-8 (2009), 497-621.

Minniti, Maria, and Wim Naudé, "What Do We Know about the Patterns and Determinants of Female Entrepreneurship across Countries?", European Journal of Development Research 22 (2010), 277-293.

Mitra, Reshmi, “The Growth Pattern of Women-Run Enterprises: An Empirical Study in India”, Journal of Developmental Entrepreneurship (2002).

Mukim, Megha, "Industry and the Urge to Cluster: A Study of the Informal Sector in India", Spatial Economics Research Centre Discussion Paper 0072 (2011).

Munshi, Kaivan, "Strength in Numbers: Networks as a Solution to Occupational Traps", Review of Economic Studies 78:3 (2011), 1069-1101.

Nataraj, Shanthi, "The Impact of Trade Liberalization on Productivity: Evidence from India's Formal and Informal Manufacturing Sectors", Journal of International Economics 85 (2011), 292-301.

Pande, Rohini, "Can Mandated Political Representation Provide Disadvantaged Minorities Policy Influence? Theory and Evidence from India", American Economic Review 93:4 (2003), 11321151 .

Pande, Rohini, and Deanna Ford, "Gender Quotas and Female Leadership: A Review”, Background Paper for the World Development Report on Gender (2011).

Parker, Simon, The Economics of Self-Employment and Entrepreneurship (Cambridge, UK: Cambridge University Press, 2009). 
Pillania, Rajesh, Madhurima Lall, and Shikha Saha, "Motives for Starting Business: Indian Women Entrepreneurs Perspectives", International Journal of Indian Culture and Business Management 3:1 (2010), 48-67.

Powley, Elizabeth, "Rwanda: The Impact of Women Legislators on Policy Outcomes Affecting Children and Families", Background Paper for State of the World's Children, UNICEF (2007).

Rosenthal, Stuart, and William Strange, "Female Entrepreneurship, Agglomeration, and a New Spatial Mismatch", Review of Economics and Statistics 94:3 (2012), 764-788.

Topalova, Petia, and Esther Duflo, "Is There Discrimination Against Women in Politics? Evidence from India”, MIT Working Paper (2004).

Verheul, Ingrid, André van Stel, and Roy Thurik, "Explaining Female and Male Entrepreneurship at the Country Level", Entrepreneurship and Regional Development 18 (2006), 151-183.

Washington, Ebonya, "Female Socialization: How Daughters Affect Their Legislator Fathers' Voting on Women's Issues", American Economic Review 98:1 (2008), 311-332.

World Bank, Gender Equality and Development, World Development Report (2012).

World Bank, Reducing Gender Based Differences in Formality and Productivity (2008). 


\section{Fig. 1: Implementation of Indian political reservations}

Timeline of state-level implementation of 73rd Amendment reservations for women

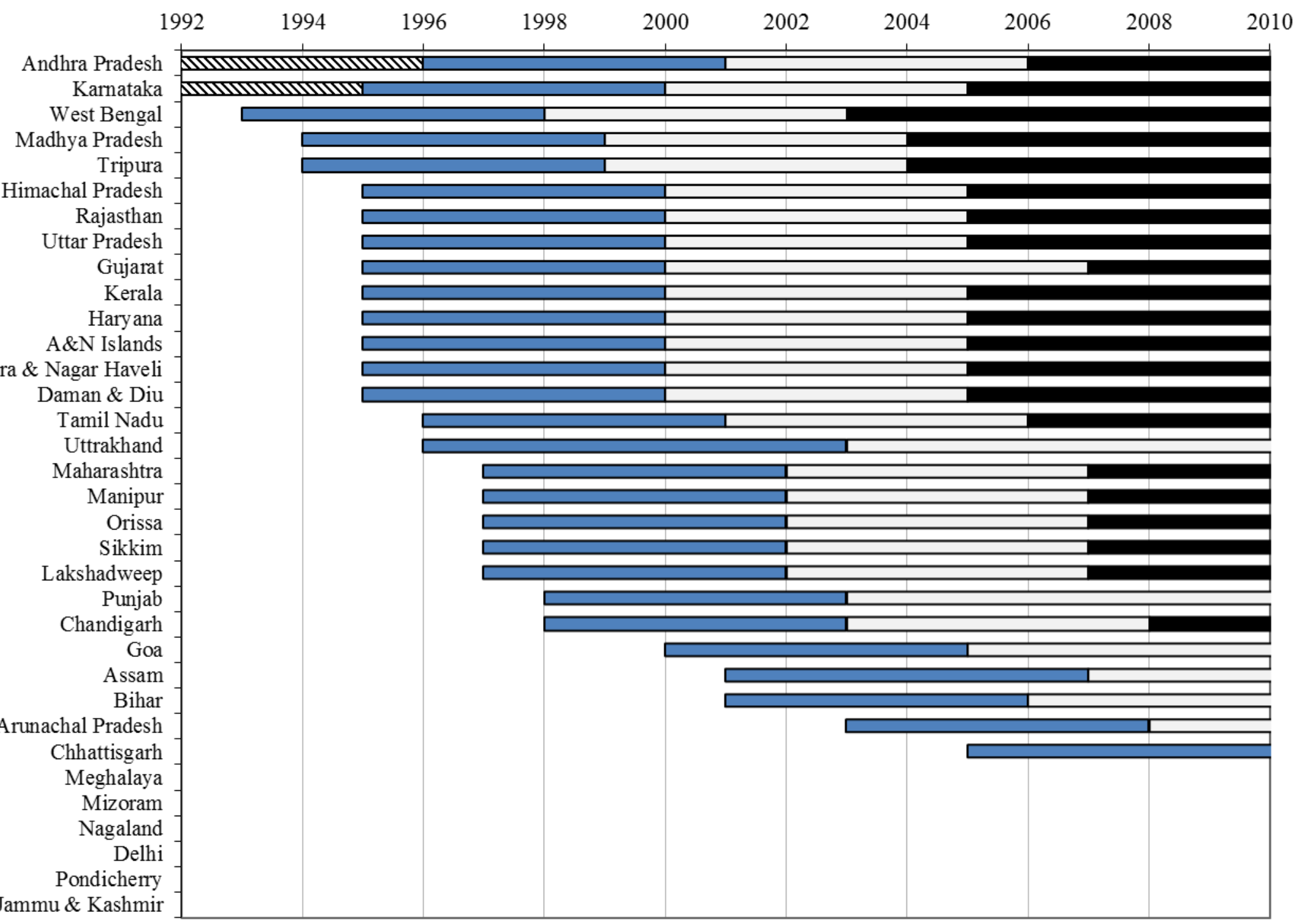




\section{Fig. 2: State-level initial conditions and timing of implementations}

\section{4 women's ownership and entrepreneurship versus timing of state-level implementations}

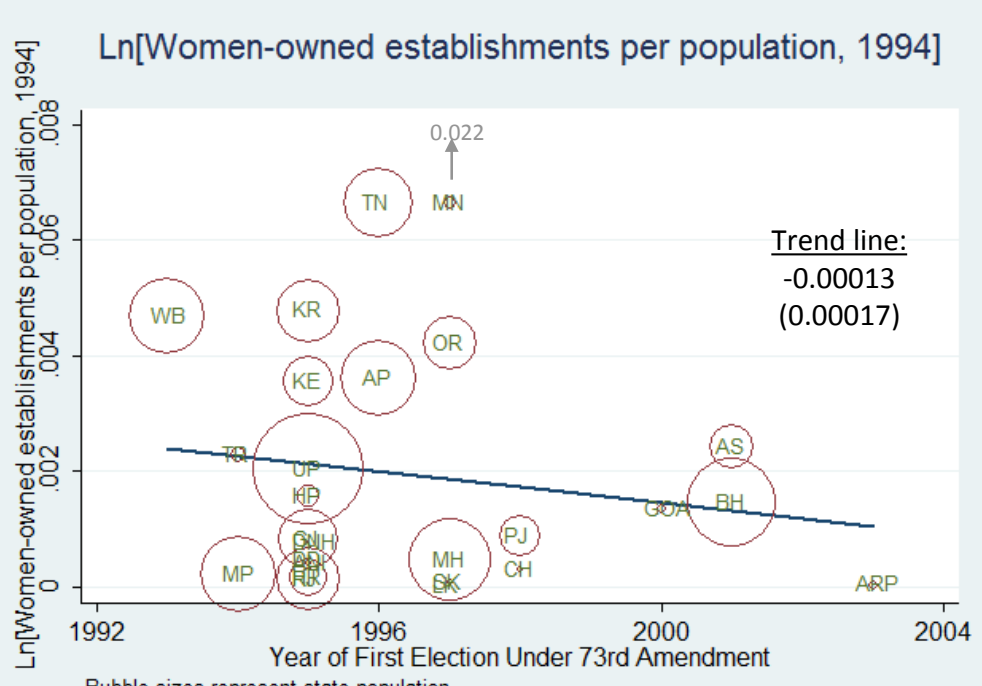

Bubble sizes represent state population.

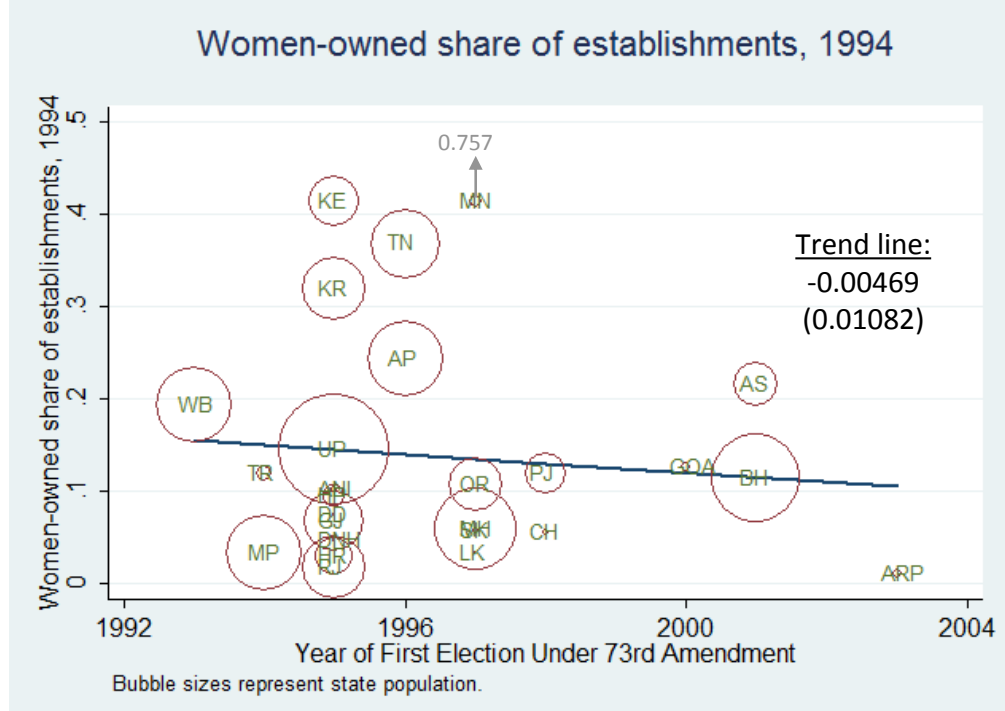

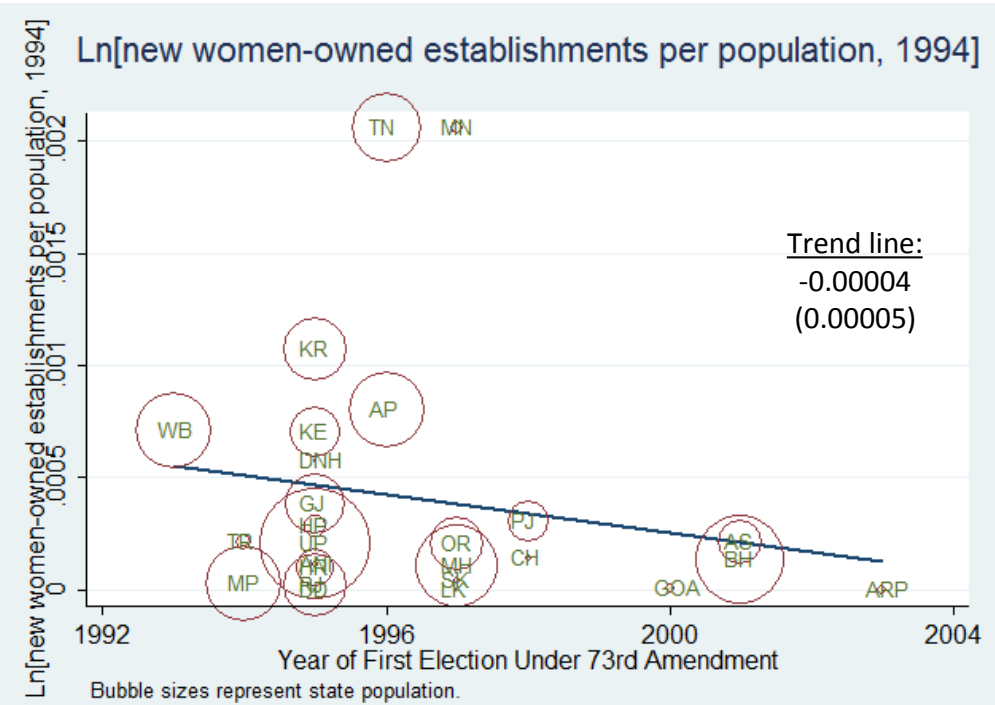

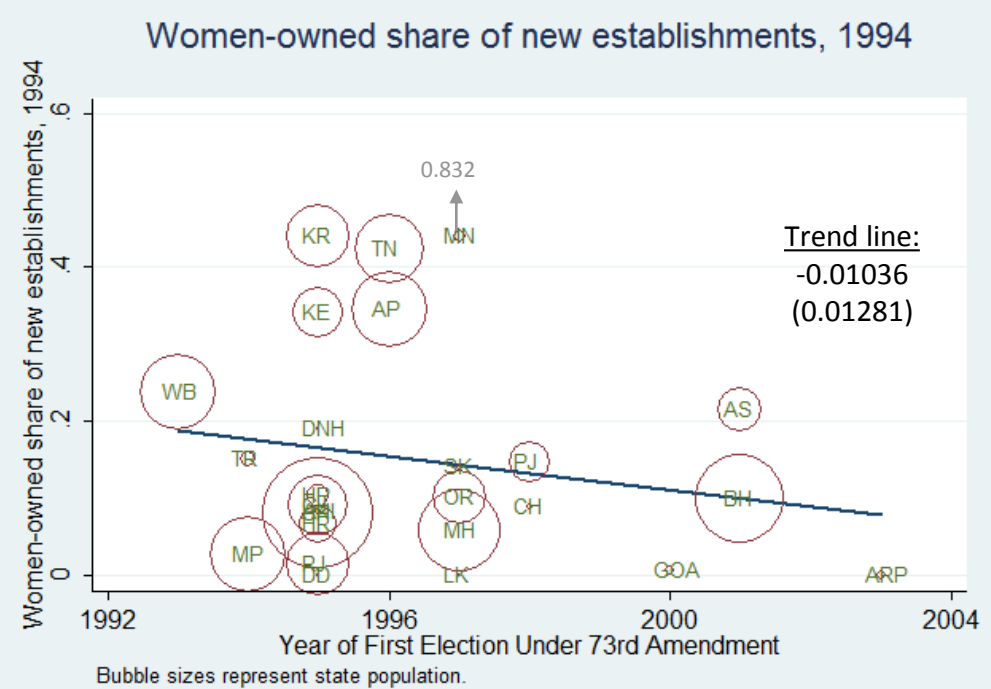




\section{Fig. 3: Figure 2 at the state-industry level}

\section{4 women's ownership and entrepreneurship versus timing of state-level implementations}
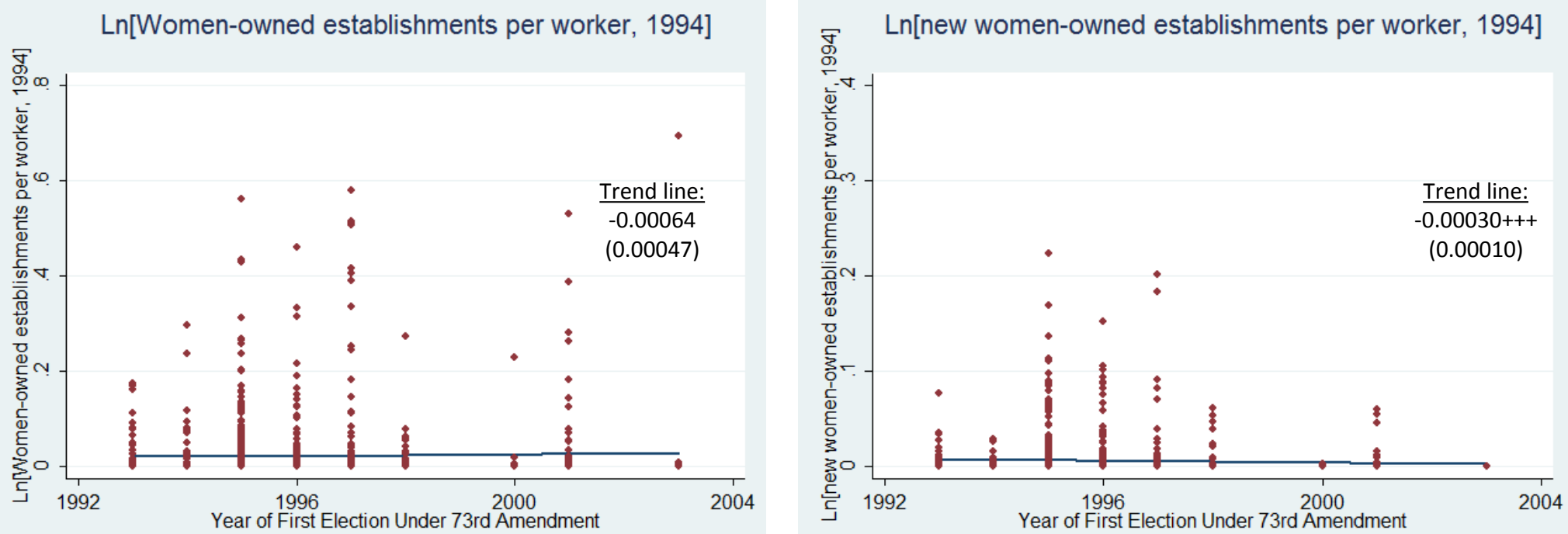

Women-owned share of establishments, 1994
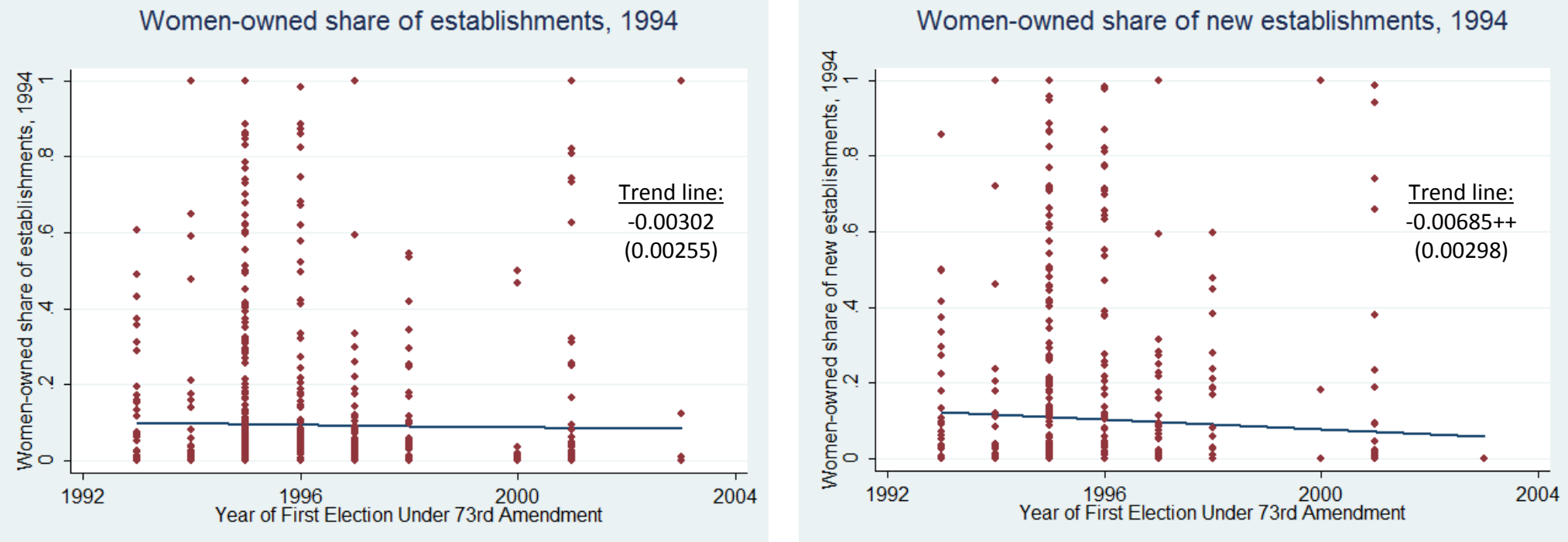

Notes: Figure plots traits of state-industries in 1994 with respect to women's ownership and entrepreneurship against the timing of each state's implementation of the $73^{\text {rd }}$ Amendment to provide political set-asides for women leaders. Trend lines are calculated with robust standard errors. 


\section{Fig. 4: Age structures in 1994 of plants by state election timing}

Age distr. of establishments (A,B) and women's shares by age group (C,D)

A. CDF distribution of women-owned establishments in 1994 across age categories, state averages

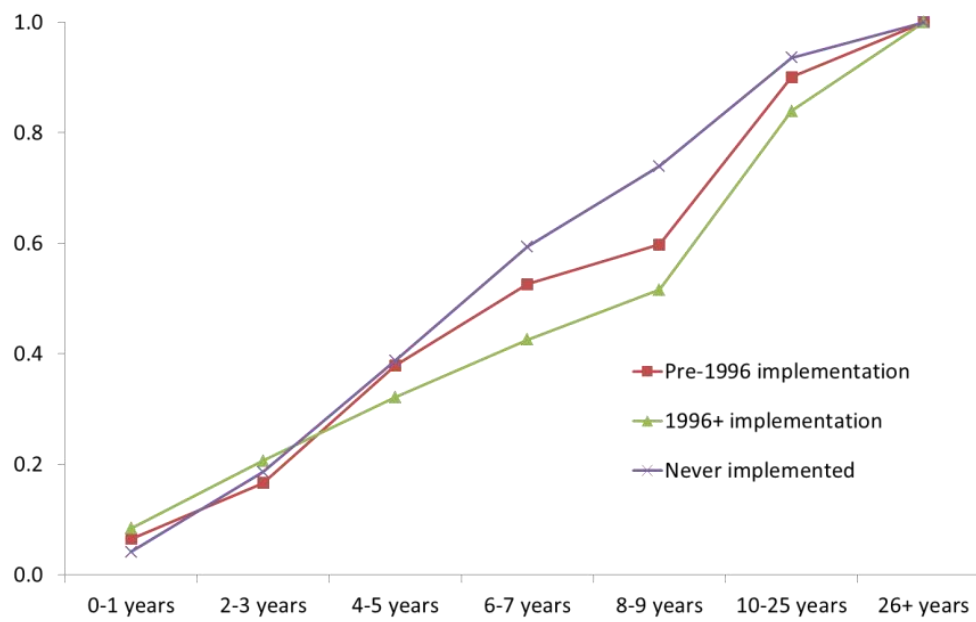

C. Share of establishments in age category that are owned by women in 1994, state averages

0.4

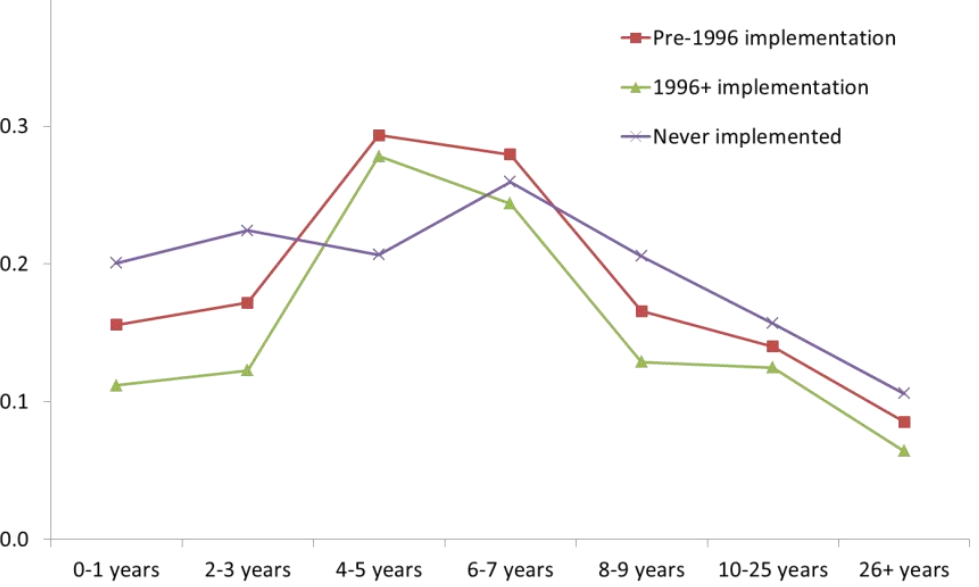

B. CDF distribution of male-owned establishments in 1994 across age categories, state averages

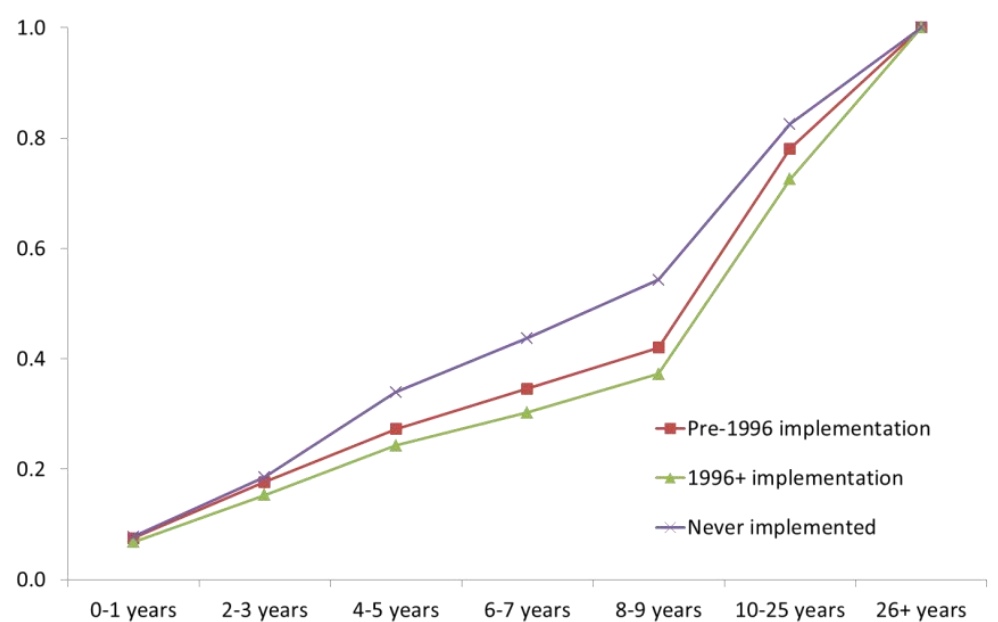

D. Normalized share of establishments in age category that are owned by women in 1994, state averages

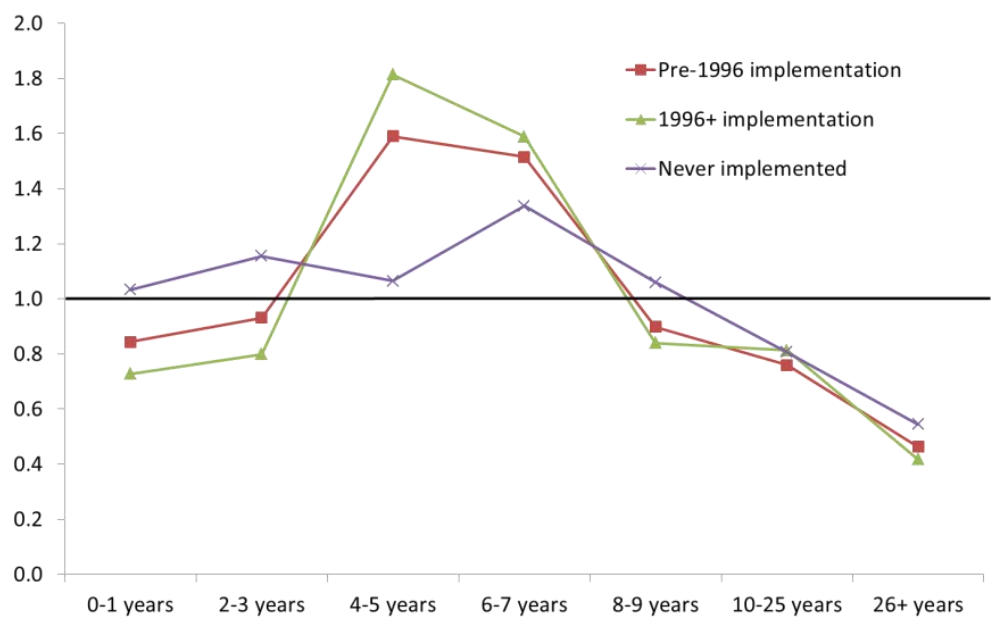

Notes: Figure depicts women's ownership rates across the establishment age distribution. Each line provides the unweighted average of states within the group specified. Panels A and $B$ document the CDFs of women- and male-owned establishments across the age distribution. Panel C provides the share of establishments in each age category that are owned by women. Panel D presents a normalized version of Panel $C$ that divides ownership shares by the average for each group overall. 


\section{Fig. 5: Dynamic timing of entry response to elections}

\section{Coefficient estimates and $90 \%$ confidence bands}

A. Log count of new women-owned businesses using state-year timing

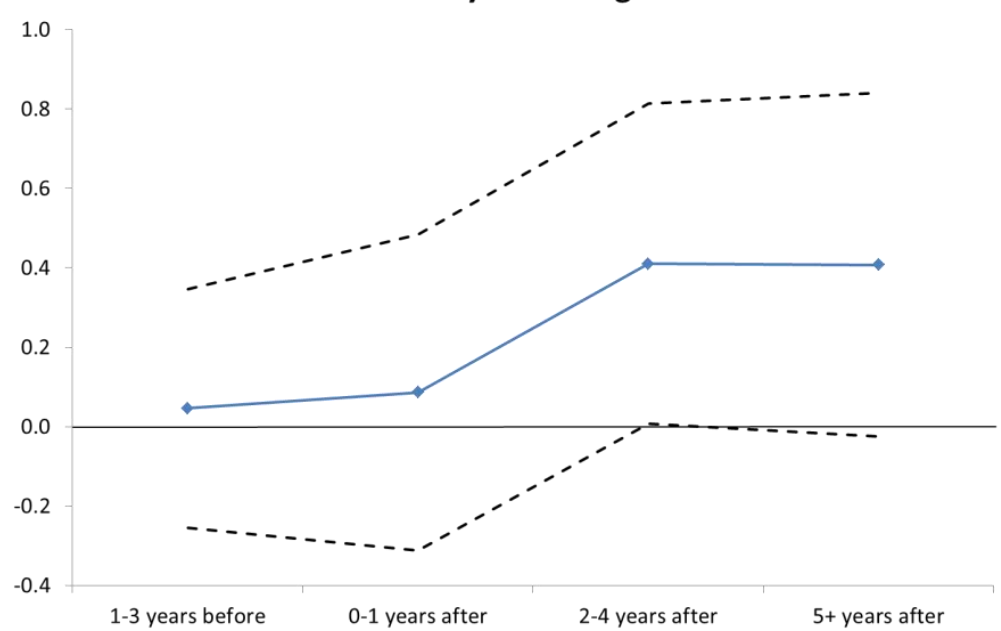

B. Log count of new male-owned businesses using state-year timing

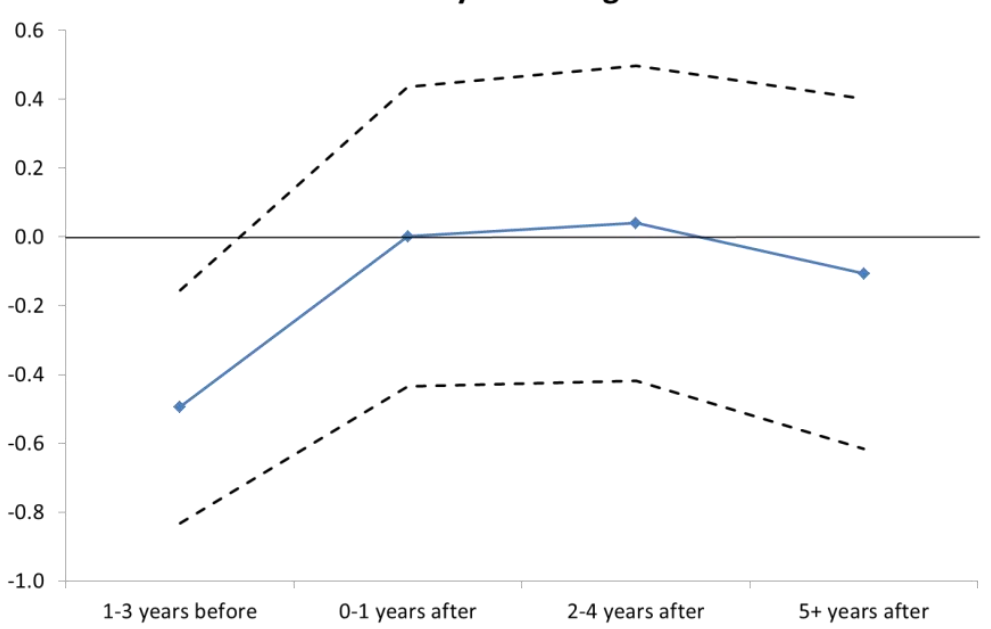

Notes: Figure reports a dynamic analysis of the entrepreneurship patterns to see if they possess a timing that links them to the implementation of political reservations. The estimations approach follows that of Table 2 but introduces four indicator variables for the timing of the elections: 1-3 years before the state's elections, $0-1$ years after the elections, 2-4 years after the elections, and 5+ years after the elections. Coefficients on these variables are relative to the period four or more years before the state's elections and non-adopting states. The dependent variable in Panel A is the log count of new women-owned businesses by state-industry-year; the dependent variable in Panel B is similarly defined for maleowned entrants. Estimations cluster standard errors at the state level and include state-industry and industry-year fixed effects. App. Table 3 provides regression estimates. 
Table 1: Descriptive statistics

\begin{tabular}{|c|c|c|c|c|c|c|c|c|}
\hline & \multicolumn{3}{|c|}{ Levels } & & & \multicolumn{3}{|c|}{ Shares of total activity } \\
\hline & 1994 & 2000 & 2005 & \multicolumn{2}{|c|}{ Growth, 1994-2005 } & 1994 & 2000 & 2005 \\
\hline & (1) & $(2)$ & (3) & (4) & $(5)$ & $(6)$ & (7) & $(8)$ \\
\hline \multicolumn{9}{|l|}{ Establishment counts $(000 \mathrm{~s})$} \\
\hline Total & 12,125 & 16,986 & 16,948 & 4,823 & $40 \%$ & & & \\
\hline Organized sector & 93 & 99 & 105 & 11 & $12 \%$ & $0.8 \%$ & $0.6 \%$ & $0.6 \%$ \\
\hline Unorganized sector & 12,032 & 16,887 & 16,843 & 4,811 & $40 \%$ & $99.2 \%$ & $99.4 \%$ & $99.4 \%$ \\
\hline Women-owned establishments & 2,037 & 4,419 & 6,176 & 4,139 & $203 \%$ & $16.8 \%$ & $26.0 \%$ & $36.4 \%$ \\
\hline Household based & 1,919 & 4,146 & 5,818 & 3,899 & $203 \%$ & $15.8 \%$ & $24.4 \%$ & $34.3 \%$ \\
\hline Non-household based & 118 & 273 & 358 & 240 & $203 \%$ & $1.0 \%$ & $1.6 \%$ & $2.1 \%$ \\
\hline \multicolumn{9}{|l|}{ Employment $(000 \mathrm{~s})$} \\
\hline Total & 34,424 & 40,702 & 40,336 & 5,912 & $17 \%$ & & & \\
\hline Organized sector & 6,775 & 6,723 & 7,470 & 695 & $10 \%$ & $19.7 \%$ & $16.5 \%$ & $18.5 \%$ \\
\hline Unorganized sector & 27,649 & 33,979 & 32,866 & 5,217 & $19 \%$ & $80.3 \%$ & $83.5 \%$ & $81.5 \%$ \\
\hline Women-owned establishments & 3,180 & 5,554 & 7,555 & 4,375 & $138 \%$ & $9.2 \%$ & $13.6 \%$ & $18.7 \%$ \\
\hline Household based & 2,882 & 4,934 & 6,800 & 3,918 & $136 \%$ & $8.4 \%$ & $12.1 \%$ & $16.9 \%$ \\
\hline Non-household based & 298 & 620 & 755 & 457 & $153 \%$ & $0.9 \%$ & $1.5 \%$ & $1.9 \%$ \\
\hline Organized sector & 6,775 & 6,723 & 7,470 & & & & & \\
\hline Male production workers & 3,702 & 3,414 & 3,361 & -342 & $-9 \%$ & $10.8 \%$ & $8.4 \%$ & $8.3 \%$ \\
\hline Female production workers & 652 & 654 & 728 & 76 & $12 \%$ & $1.9 \%$ & $1.6 \%$ & $1.8 \%$ \\
\hline Others (Supervisory, contractors, etc.) & 2,421 & 2,656 & 3,382 & 961 & $40 \%$ & $7.0 \%$ & $6.5 \%$ & $8.4 \%$ \\
\hline Unorganized sector & 27,649 & 33,979 & 32,866 & & & & & \\
\hline Male persons engaged & 18,458 & 23,330 & 21,272 & 2,814 & $15 \%$ & $53.6 \%$ & $57.3 \%$ & $52.7 \%$ \\
\hline Female persons engaged & 9,191 & 10,649 & 11,594 & 2,403 & $26 \%$ & $26.7 \%$ & $26.2 \%$ & $28.7 \%$ \\
\hline \multicolumn{9}{|l|}{ Output (MM 2005 USD at PPP) } \\
\hline Total & 459,689 & 650,566 & 870,224 & 410,535 & $89 \%$ & & & \\
\hline Organized sector & 384,375 & 501,638 & 705,215 & 320,840 & $83 \%$ & $83.6 \%$ & $77.1 \%$ & $81.0 \%$ \\
\hline Unorganized sector & 75,314 & 148,927 & 165,009 & 89,695 & $119 \%$ & $16.4 \%$ & $22.9 \%$ & $19.0 \%$ \\
\hline Women-owned establishments & 3,154 & 7,142 & 10,362 & 7,208 & $229 \%$ & $0.7 \%$ & $1.1 \%$ & $1.2 \%$ \\
\hline Household based & 2,071 & 3,194 & 5,730 & 3,659 & $177 \%$ & $0.5 \%$ & $0.5 \%$ & $0.7 \%$ \\
\hline Non-household based & 1,083 & 3,948 & 4,632 & 3,549 & $328 \%$ & $0.2 \%$ & $0.6 \%$ & $0.5 \%$ \\
\hline
\end{tabular}

Source: Authors' calculations using Annual Survey of Industries and National Sample Survey Organisation - Employment/Unemployment Survey (various rounds). 
Table 2: Estimations of main effects of state political reservations on women's economic activity

\begin{tabular}{|c|c|c|c|c|c|c|c|}
\hline & $\begin{array}{c}\text { Log count of } \\
\text { new women- } \\
\text { owned } \\
\text { establishments } \\
\text { in unorganized } \\
\text { sector }\end{array}$ & $\begin{array}{c}\text { Log } \\
\text { employment in } \\
\text { new women- } \\
\text { owned } \\
\text { establishments } \\
\text { in unorganized } \\
\text { sector }\end{array}$ & $\begin{array}{c}\text { Log count of } \\
\text { women-owned } \\
\text { establishments } \\
\text { in unorganized } \\
\text { sector }\end{array}$ & $\begin{array}{l}\text { Log women } \\
\text { employed }\end{array}$ & $\begin{array}{c}\text { Log women } \\
\text { employed in } \\
\text { male-owned } \\
\text { establishments } \\
\text { in unorganized } \\
\text { sector }\end{array}$ & $\begin{array}{l}\text { Log women } \\
\text { employed in } \\
\text { women-owned } \\
\text { establishments } \\
\text { in unorganized } \\
\text { sector }\end{array}$ & $\begin{array}{l}\text { Log women } \\
\text { employed in } \\
\text { organized } \\
\text { sector }\end{array}$ \\
\hline & $(1)$ & $(2)$ & (3) & $(4)$ & $(5)$ & $(6)$ & $(7)$ \\
\hline & \multicolumn{7}{|c|}{ A. Base estimation } \\
\hline$(0,1)$ state has political reservations & $\begin{array}{l}0.391+ \\
(0.214)\end{array}$ & $\begin{array}{l}0.421+ \\
(0.242)\end{array}$ & $\begin{array}{c}0.215 \\
(0.289)\end{array}$ & $\begin{array}{c}0.015 \\
(0.311)\end{array}$ & $\begin{array}{c}0.075 \\
(0.266)\end{array}$ & $\begin{array}{c}0.137 \\
(0.299)\end{array}$ & $\begin{array}{c}0.039 \\
(0.154)\end{array}$ \\
\hline Observations & 3606 & 3606 & 3606 & 3606 & 3606 & 3606 & 3606 \\
\hline Adjusted R-squared & 0.733 & 0.701 & 0.818 & 0.825 & 0.817 & 0.808 & 0.838 \\
\hline \multirow[t]{2}{*}{ Controls } & \multicolumn{7}{|c|}{ State $\mathrm{x}$ industry and Industry $\mathrm{x}$ year fixed effects } \\
\hline & \multicolumn{7}{|c|}{ B. Panel A including male analogue of activity in state-industry-year } \\
\hline$(0,1)$ state has political reservations & $\begin{array}{l}0.333+ \\
(0.194)\end{array}$ & $\begin{array}{c}0.359 \\
(0.216)\end{array}$ & $\begin{array}{c}0.233 \\
(0.262)\end{array}$ & $\begin{array}{c}0.089 \\
(0.205)\end{array}$ & $\begin{array}{c}0.122 \\
(0.182)\end{array}$ & $\begin{array}{c}0.001 \\
(0.200)\end{array}$ & $\begin{array}{l}-0.004 \\
(0.110)\end{array}$ \\
\hline $\begin{array}{l}\text { DV analogue for male-owned } \\
\text { establishments in state-industry-year }\end{array}$ & $\begin{array}{c}0.118+++ \\
(0.024)\end{array}$ & $\begin{array}{c}0.111+++ \\
(0.024)\end{array}$ & $\begin{array}{c}0.216+++ \\
(0.030)\end{array}$ & $\begin{array}{c}0.442+++ \\
(0.048)\end{array}$ & $\begin{array}{c}0.389+++ \\
(0.055)\end{array}$ & $\begin{array}{c}0.515+++ \\
(0.043)\end{array}$ & $\begin{array}{c}0.366+++ \\
(0.048)\end{array}$ \\
\hline Observations & 3606 & 3606 & 3606 & 3606 & 3606 & 3606 & 3606 \\
\hline Adjusted R-squared & 0.737 & 0.706 & 0.824 & 0.853 & 0.840 & 0.865 & 0.855 \\
\hline Controls & \multicolumn{7}{|c|}{ State $\mathrm{x}$ industry and Industry $\mathrm{x}$ year fixed effects } \\
\hline
\end{tabular}

Notes: Regressions quantify adjustments in women's entrepreneurship and employment in India surrounding the implementation of state-level political reservations for women. Column headers indicate dependent variables. Regressions contain 3606 state-industry observations and include state $\mathrm{x}$ industry and industry $\mathrm{x}$ year fixed effects. Panel A includes a modified

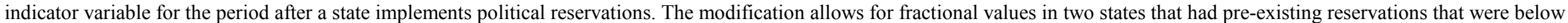

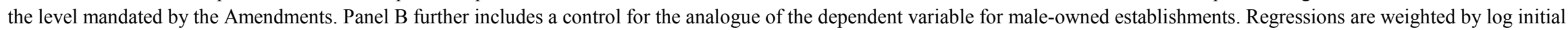
employment in state-industry in 1994 and cluster standard errors by state.,+++++ , and + indicate statistical significance at a $1 \%, 5 \%$, and $10 \%$ level, respectively. 
Table 3: Disaggregating the form of new women-owned establishments in unorganized sector

\begin{tabular}{|c|c|c|c|c|c|c|c|}
\hline & \multicolumn{7}{|c|}{ DV is log count of new women-owned establishments in unorganized sector by state-industry: } \\
\hline & Total & $\begin{array}{l}\text { Household } \\
\text { based }\end{array}$ & $\begin{array}{l}\text { Non-household } \\
\text { based }\end{array}$ & $\begin{array}{l}\text { With three or } \\
\text { fewer } \\
\text { employees }\end{array}$ & $\begin{array}{c}\text { With four or } \\
\text { more } \\
\text { employees }\end{array}$ & $\begin{array}{c}\text { Without } \\
\text { external } \\
\text { financing }\end{array}$ & $\begin{array}{l}\text { With external } \\
\text { financing }\end{array}$ \\
\hline & $(1)$ & $(2)$ & (3) & $(4)$ & $(5)$ & $(6)$ & $(7)$ \\
\hline & \multicolumn{7}{|c|}{ A. Base estimation } \\
\hline$(0,1)$ state has political reservations & $\begin{array}{l}0.391+ \\
(0.214)\end{array}$ & $\begin{array}{l}0.336+ \\
(0.192)\end{array}$ & $\begin{array}{c}0.063 \\
(0.145)\end{array}$ & $\begin{array}{l}0.336+ \\
(0.198)\end{array}$ & $\begin{array}{c}0.173 \\
(0.126)\end{array}$ & $\begin{array}{l}0.376+ \\
(0.203)\end{array}$ & $\begin{array}{c}0.144 \\
(0.130)\end{array}$ \\
\hline Observations & 3606 & 3606 & 3606 & 3606 & 3606 & 3606 & 3606 \\
\hline Adjusted R-squared & 0.733 & 0.743 & 0.528 & 0.737 & 0.355 & 0.732 & 0.457 \\
\hline Controls & \multicolumn{7}{|c|}{ State $\mathrm{x}$ industry and Industry $\mathrm{x}$ year fixed effects } \\
\hline \multicolumn{8}{|c|}{ B. Panel A including male analogue of activity in state-industry-year } \\
\hline$(0,1)$ state has political reservations & $\begin{array}{l}0.333+ \\
(0.194)\end{array}$ & $\begin{array}{c}0.264 \\
(0.170)\end{array}$ & $\begin{array}{c}0.042 \\
(0.139)\end{array}$ & $\begin{array}{c}0.286 \\
(0.187)\end{array}$ & $\begin{array}{c}0.158 \\
(0.120)\end{array}$ & $\begin{array}{l}0.336+ \\
(0.186)\end{array}$ & $\begin{array}{c}0.132 \\
(0.121)\end{array}$ \\
\hline $\begin{array}{l}\text { DV analogue for male-owned } \\
\text { establishments in state-industry-year }\end{array}$ & $\begin{array}{l}0.118+++ \\
(0.024)\end{array}$ & $\begin{array}{c}0.113+++ \\
(0.023)\end{array}$ & $\begin{array}{c}0.071+++ \\
(0.019)\end{array}$ & $\begin{array}{c}0.099+++ \\
(0.025)\end{array}$ & $\begin{array}{l}0.047+ \\
(0.024)\end{array}$ & $\begin{array}{l}0.092+++ \\
(0.031)\end{array}$ & $\begin{array}{l}0.049+ \\
(0.027)\end{array}$ \\
\hline Observations & 3606 & 3606 & 3606 & 3606 & 3606 & 3606 & 3606 \\
\hline Adjusted R-squared & 0.737 & 0.748 & 0.531 & 0.740 & 0.358 & 0.734 & 0.459 \\
\hline Controls & \multicolumn{7}{|c|}{ State $\mathrm{x}$ industry and Industry $\mathrm{x}$ year fixed effects } \\
\hline
\end{tabular}

Notes: See Table 2. 
DV is log count of new women-owned establishments in unorganized sector by state-industry

Industry trait used in interaction, calculated in 1994 at the national level:

\begin{tabular}{|c|c|c|c|c|c|c|}
\hline $\begin{array}{l}\text { Log share of } \\
\text { unorganized } \\
\text { establishments } \\
\text { owned by } \\
\text { women }\end{array}$ & $\begin{array}{l}\text { Log share of } \\
\text { unorganized } \\
\text { establishments } \\
\text { that are } \\
\text { household- } \\
\text { based }\end{array}$ & $\begin{array}{l}\text { Log share of } \\
\text { unorganized } \\
\text { establishments } \\
\text { that are } \\
\text { household- } \\
\text { based and } \\
\text { women-owned }\end{array}$ & $\begin{array}{l}\text { Log average } \\
\text { establishment } \\
\text { size }\end{array}$ & $\begin{array}{l}\text { Log average } \\
\text { value-added } \\
\text { per worker }\end{array}$ & $\begin{array}{l}\text { Log average } \\
\text { fixed capital } \\
\text { per worker }\end{array}$ & $\begin{array}{l}\text { Log average } \\
\text { financial } \\
\text { liabilities as a } \\
\text { share of output }\end{array}$ \\
\hline
\end{tabular}

(1)

$0.332++$

$(0.129)$

3606

0.737

Adjusted R-squared

Controls

$(0,1)$ state has political reservations

$\mathrm{x}$ industry trait in column header

DV analogue for male-owned

establishments in state-industry-year

Observations

Adjusted R-squared

Controls

(2) (3)

(4)

(5)

(6)

(7)

A. Base estimation

0.224

$0.399+++$
$(0.135)$
3606

$-0.291++$

$-0.192$

$-0.280+$

(0.151)

0.110

(0.121)

(0.133)

(0.146)

3606

(0.092)

3606
0.736

0.738

3606
0.735

3606

0.735

3606

State $\mathrm{x}$ industry, State $\mathrm{x}$ year, and Industry $\mathrm{x}$ year fixed effects

B. Panel A including male analogue of activity in state-industry-year

$\begin{array}{ccccccc}0.335+++ & 0.211+ & 0.390+++ & -0.263++ & -0.184 & -0.277+ & 0.108 \\ (0.128) & (0.119) & (0.134) & (0.132) & (0.145) & (0.150) & (0.091) \\ 0.098+++ & 0.096+++ & 0.096+++ & 0.105+++ & 0.107+++ & 0.107+++ & 0.097+++ \\ (0.031) & (0.031) & (0.031) & (0.036) & (0.036) & (0.036) & (0.031) \\ 3606 & 3606 & 3606 & 3606 & 3606 & 3606 & 3606 \\ 0.740 & 0.739 & 0.740 & 0.738 & 0.738 & 0.738 & 0.739\end{array}$

State $\mathrm{x}$ industry, State $\mathrm{x}$ year, and Industry $\mathrm{x}$ year fixed effects

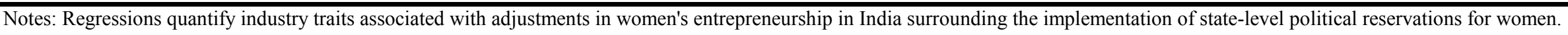

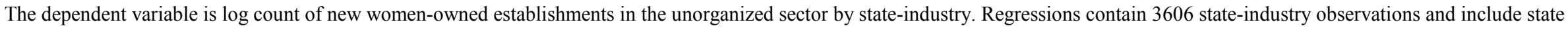
$\mathrm{x}$ industry, industry $\mathrm{x}$ year, and state $\mathrm{x}$ year fixed effects. Panel A includes a modified indicator variable for the period after a state implements the political reservation interacted with the industry trait from 1994 given in the column header. The modification allows for fractional values in two states that had pre-existing set-asides that were below the level mandated by the Amendments. Fixed effects absorb the main effects of the interactions. Industry traits are expressed in logarithms. Panel B further includes a control for the analogue of the dependent

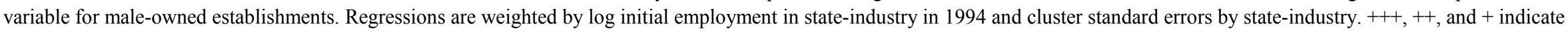
statistical significance at a $1 \%, 5 \%$, and $10 \%$ level, respectively. 
Table 5: Variations on Table 4's estimation design and sample composition

\begin{tabular}{|c|c|c|c|c|c|c|}
\hline $\begin{array}{c}\text { Baseline } \\
\text { estimation } \\
\text { from Column } 3 \\
\text { of Table } 4\end{array}$ & $\begin{array}{l}\text { Using the } \\
\text { coding scheme } \\
\text { of Iyer et al. } \\
(2012)\end{array}$ & $\begin{array}{l}\text { Dropping } \\
\text { Andhra } \\
\text { Pradesh and } \\
\text { Karnataka }\end{array}$ & $\begin{array}{c}\text { Dropping all } \\
\text { non-adopting } \\
\text { states }\end{array}$ & $\begin{array}{l}\text { Dropping the } \\
\text { two industry } \\
\text { groups with } \\
\text { the largest } \\
\text { women- } \\
\text { ownership } \\
\text { shares }\end{array}$ & $\begin{array}{c}\text { Clustering } \\
\text { standard errors } \\
\text { at the state } \\
\text { level }\end{array}$ & $\begin{array}{l}\text { Dropping state } \\
\text { x year fixed } \\
\text { effects and } \\
\text { controlling for } \\
\text { unreported } \\
\text { main effect }\end{array}$ \\
\hline$(1)$ & $(2)$ & (3) & (4) & $\overline{(5)}$ & (6) & $(7)$ \\
\hline \multicolumn{7}{|c|}{ A. Base estimation } \\
\hline $\begin{array}{c}0.399+++ \\
(0.135)\end{array}$ & $\begin{array}{c}0.397+++ \\
(0.129)\end{array}$ & $\begin{array}{c}0.335++ \\
(0.140)\end{array}$ & $\begin{array}{c}0.443+++ \\
(0.154)\end{array}$ & $\begin{array}{c}0.378+++ \\
(0.142)\end{array}$ & $\begin{array}{l}0.399+ \\
(0.202)\end{array}$ & $\begin{array}{c}0.388+++ \\
(0.135)\end{array}$ \\
\hline 3606 & 3606 & 3300 & 2834 & 3358 & 3606 & 3606 \\
\hline 0.738 & 0.738 & 0.724 & 0.738 & 0.723 & 0.738 & 0.735 \\
\hline \multicolumn{7}{|c|}{ State $\mathrm{x}$ industry, State x year, and Industry x year fixed effects } \\
\hline \multicolumn{7}{|c|}{ B. Panel A including male analogue of activity in state-industry-year } \\
\hline $\begin{array}{c}0.390+++ \\
(0.134)\end{array}$ & $\begin{array}{c}0.388+++ \\
(0.127)\end{array}$ & $\begin{array}{c}0.327++ \\
(0.139)\end{array}$ & $\begin{array}{c}0.428+++ \\
(0.153)\end{array}$ & $\begin{array}{c}0.374+++ \\
(0.143)\end{array}$ & $\begin{array}{l}0.390+ \\
(0.197)\end{array}$ & $\begin{array}{c}0.378+++ \\
(0.133)\end{array}$ \\
\hline $\begin{array}{c}0.096+++ \\
(0.031)\end{array}$ & $\begin{array}{c}0.096+++ \\
(0.031)\end{array}$ & $\begin{array}{c}0.106+++ \\
(0.033)\end{array}$ & $\begin{array}{c}0.094+++ \\
(0.035)\end{array}$ & $\begin{array}{c}0.078++ \\
(0.032)\end{array}$ & $\begin{array}{c}0.096+++ \\
(0.027)\end{array}$ & $\begin{array}{c}0.116+++ \\
(0.031)\end{array}$ \\
\hline 3606 & 3606 & 3300 & 2834 & 3358 & 3606 & 3606 \\
\hline 0.740 & 0.740 & 0.728 & 0.740 & 0.725 & 0.740 & 0.739 \\
\hline
\end{tabular}

$(0,1)$ state has political reservations $\mathrm{x} \log$ women HH share, 1994

DV analogue for male-owned

establishments in state-industry-year

Observations$$
\text { Adjusted R-squared }
$$

Controls

State $\mathrm{x}$ industry, State $\mathrm{x}$ year, and Industry $\mathrm{x}$ year fixed effects 
Table 6: Border discontinuity analysis of state political reservations on women's economic activity

\begin{tabular}{|c|c|c|c|c|c|c|}
\hline & \multicolumn{6}{|c|}{ DV is the ratio of the indicated trait across the bordering districts } \\
\hline & $\begin{array}{c}\text { Log count of } \\
\text { new women- } \\
\text { owned } \\
\text { establishments } \\
\text { in unorganized } \\
\text { sector }\end{array}$ & $\begin{array}{c}\text { Log } \\
\text { employment in } \\
\text { new women- } \\
\text { owned } \\
\text { establishments } \\
\text { in unorganized } \\
\text { sector }\end{array}$ & $\begin{array}{c}\text { Log count of } \\
\text { women-owned } \\
\text { establishments } \\
\text { in unorganized } \\
\text { sector }\end{array}$ & $\begin{array}{l}\text { Log women } \\
\text { employed in } \\
\text { unorganized } \\
\text { sector }\end{array}$ & $\begin{array}{c}\text { Log women } \\
\text { employed in } \\
\text { male-owned } \\
\text { establishments } \\
\text { in unorganized } \\
\text { sector }\end{array}$ & $\begin{array}{c}\text { Log women } \\
\text { employed in } \\
\text { women-owned } \\
\text { establishments } \\
\text { in unorganized } \\
\text { sector }\end{array}$ \\
\hline & $(1)$ & $(2)$ & (3) & (4) & $(5)$ & $(6)$ \\
\hline & \multicolumn{6}{|c|}{ A. Base estimation } \\
\hline Gap in years of implementation & $\begin{array}{c}0.555+++ \\
(0.139)\end{array}$ & $\begin{array}{l}0.732+++ \\
(0.157)\end{array}$ & $\begin{array}{c}0.226++ \\
(0.105)\end{array}$ & $\begin{array}{l}0.212+++ \\
(0.062)\end{array}$ & $\begin{array}{c}0.033 \\
(0.043)\end{array}$ & $\begin{array}{c}0.347+++ \\
(0.101)\end{array}$ \\
\hline Observations & 352 & 352 & 352 & 352 & 352 & 352 \\
\hline Adjusted R-squared & 0.271 & 0.296 & 0.398 & 0.573 & 0.481 & 0.383 \\
\hline \multirow[t]{2}{*}{ Controls } & \multicolumn{6}{|c|}{ State fixed effects and the ratio of the specified DV in 1994 for the bordering districts } \\
\hline & \multicolumn{6}{|c|}{ B. Panel A including male analogue of activity in district pair } \\
\hline Gap in years of implementation & $\begin{array}{l}0.458+++ \\
(0.130)\end{array}$ & $\begin{array}{l}0.664+++ \\
(0.147)\end{array}$ & $\begin{array}{l}0.178+ \\
(0.098)\end{array}$ & $\begin{array}{c}0.002 \\
(0.067)\end{array}$ & $\begin{array}{c}-0.287+++ \\
(0.072)\end{array}$ & $\begin{array}{l}0.184+ \\
(0.100)\end{array}$ \\
\hline $\begin{array}{l}\text { DV analogue for male-owned } \\
\text { establishments in } 2005\end{array}$ & $\begin{array}{l}0.502+++ \\
(0.085)\end{array}$ & $\begin{array}{l}0.505+++ \\
(0.073)\end{array}$ & $\begin{array}{l}0.956+++ \\
(0.140)\end{array}$ & $\begin{array}{l}0.806+++ \\
(0.100)\end{array}$ & $\begin{array}{l}0.992+++ \\
(0.156)\end{array}$ & $\begin{array}{l}0.288+++ \\
(0.058)\end{array}$ \\
\hline Observations & 352 & 352 & 352 & 352 & 352 & 352 \\
\hline Adjusted R-squared & 0.387 & 0.424 & 0.507 & 0.714 & 0.676 & 0.503 \\
\hline Controls & \multicolumn{6}{|c|}{ State fixed effects and the ratio of the specified DV in 1994 for the bordering districts } \\
\hline
\end{tabular}


Table 7: Average establishment traits by gender of owner

\begin{tabular}{|c|c|c|c|c|c|}
\hline & $\begin{array}{c}\text { Total } \\
\text { shipments }\end{array}$ & $\begin{array}{c}\text { Total } \\
\text { employment }\end{array}$ & Fixed assets & $\begin{array}{l}\text { Output per } \\
\text { employee }\end{array}$ & $\begin{array}{l}\text { Assets per } \\
\text { employee }\end{array}$ \\
\hline & $(1)$ & $(2)$ & (3) & $(4)$ & $(5)$ \\
\hline & \multicolumn{5}{|c|}{ A. Averages over 1994-2005 period } \\
\hline Female-owned establishments & 1614 & 1.35 & 909 & 810 & 635 \\
\hline Male-owned establishments & 8802 & 2.26 & 2841 & 2818 & 1151 \\
\hline \multirow[t]{2}{*}{ Female-to-male ratio } & $18 \%$ & $60 \%$ & $32 \%$ & $29 \%$ & $55 \%$ \\
\hline & \multicolumn{5}{|c|}{ B. Trend in ratio during the $1994-2005$ period } \\
\hline Ratio in 1994 & $29 \%$ & $67 \%$ & $31 \%$ & $37 \%$ & $38 \%$ \\
\hline Ratio in 2000 & $17 \%$ & $58 \%$ & $34 \%$ & $29 \%$ & $58 \%$ \\
\hline Ratio in 2005 & $15 \%$ & $54 \%$ & $31 \%$ & $24 \%$ & $53 \%$ \\
\hline
\end{tabular}

Notes: Tabulations depict traits of establishments by gender of business owner taken from NSS. 


\title{
Political Reservations and Women's Entrepreneurship in India
}

\author{
Online Appendix
}

\begin{abstract}
A1. Empirical Analysis
This appendix provides additional empirical analyses to support those in the main text. App. Tables 1-5 are mentioned directly in the main analysis. An earlier draft of this paper also confirms the robustness of the household-based response when using estimations based upon cells with four dimensions: state, industry, year, and establishment type. These estimations are available from the authors upon request.
\end{abstract}

\section{A2. Extended Discussion of Mechanisms}

Section 6 considers the mechanisms that might lie behind substantial growth in women's entrepreneurship after the state-level implementations of political reservations for women leaders. This appendix provides more direct evidence on three channels: reporting bias, access to government contracts and business, and access to finance. We also provide a more extended discussion of the literature behind the female industrial networks highlighted when discussing the infrastructure and aspiration channels.

\section{Additional Background}

As a second background piece to Table 7, Appendix Table 6 presents the breakdown of employment shares and mean wages from five rounds of the NSSO's household-level Employment-Unemployment survey. These figures highlight two important features for us. First, the share of manufacturing in these surveys fluctuates between $3 \%$ and $4 \%$ during this period. ${ }^{1}$

${ }^{1}$ There is an important difference in what the household surveys capture with respect to labor force activities. Employment shares generated from the household data rely on the industry code reported by respondents' "usual principal activity". It is likely the case that the principal activity for many small-scale business owners 
This stability suggests that our trends and results are not reflecting some systematic transition from a second sector. Moreover, the relative wage points for manufacturing are at the low end of the scale compared to other major activity types (comparable to agriculture/mining and substantially less than services and transportation). These earnings distributions, while not separating out owner earnings from wage workers, suggest that most of the induced entry from outside manufacturing that we are observing is likely to have come from unpaid domestic work or from shifts away from agriculture/mining. An appreciation of this margin is again helpful for evaluating potential channels behind these entry responses. See also the related analysis in Ghani, Kanbur, and O'Connell (2013).

\section{Potential Channel: Reporting Bias}

Iyer et al. (2012) find that reported crimes against women increased after state-level implementations of political reservations. They credit this increase not to higher underlying crime rates, but instead greater confidence among women to report crimes. One possible channel for our findings is that a similar growth in confidence or security led women to be more likely to report their household-based establishments after the reservations were implemented.

We doubt that this type of phenomena is behind our work for two reasons. First, conversations with experts on Indian data and the NSSO surveying procedures have not raised flags about this concern. As discussed in Section 3, the structure of the NSSO sampling frames does not build upon features like tax payments or business registrations, instead being derived from the Economic Census and household enumeration. This NSSO design limits the potential for any structural response being captured by our data due to these reforms. As these firms are legally permitted to be unorganized, there is no incentive to evade surveys. We have also identified a field in the NSSO that allows the enumerator to indicate whether respondents appear to be non-responsive or evasive. While the variable is only modestly populated, we have not identified any patterns to suggest behavioral changes of female-owned establishments around the reforms.

(especially female, household-based entrepreneurs) is indeed other than their manufacturing activity. In the establishment surveys, businesses are surveyed regardless of the intensity with which the owner is involved. 
Second, the pattern of results speaks against this interpretation. We find that entry increased disproportionately in industries where women establishment owners were more concentrated before the reforms nationally. It seems to us unlikely that there would have been systematically more under-reporting in industries where women's ownership rates were very high.

\section{Potential Channel: Access to Government Contracts or Business}

A second potential channel is that placing women in political positions led to increased government contracts and related business flowing to women-owned establishments, which prompted the higher entry rates. This could have been due to politicians enacting explicit setasides of government contracts for women, favoritism in how contracts were awarded (or the weakening of a prior bias towards male-owned businesses), and/or the general redistribution of government expenditure towards industries and goods where women-owned businesses were better able to secure and fulfill contracts (without explicit set-asides or changes in how contracts are awarded).

Two questions on the NSSO survey inquire about the extent to which the manufacturing establishment either buys from or sells to the government. The questions are only included on the surveys after 2000, so we are unable to undertake a full quantitative analysis in a pre-post format of their response such as we did in Table 3 on other dimensions. Yet, the data are useful for understanding that it is unlikely that the access-to-the-government hypothesis accounts for the bulk of our observed response.

This is most easily observed with the raw statistics. The data for 2000 and 2005 report very limited government business dealings for most manufacturing establishments-less than $1 \%$ of establishments report output being sold to government agencies in any year. Even if substantial under-reporting existed for this channel, this very low share is mismatched to the large entry response observed after the elections.

Likewise, the data in their raw format do not align very well with the strong householdbased nature of the women's entry. In the 2000 survey, $61 \%$ of those establishments that report government business dealings are establishments that are also based in households. While a majority, this share is significantly less than the $94 \%$ of women-owned establishments that are 
based in households. The fact that the government interacts more frequently with larger businesses and independent facilities is not surprising. The second mismatch is that it is difficult for a government access channel that operates disproportionately through establishments with independent facilities to account for an entry response occurring disproportionately among household-based businesses.

A second approach is to look for evidence regarding the access-to-the-government hypothesis through the industry-level interaction approach used in the core results of Table 4. The advantage of this approach is that we do not need to observe contracts themselves, should they be under-reported, but instead only look for evidence in relative responses across industries that interact extensively with the government versus those who do not. The measurement of this industry-level dependency for India as a whole is much easier and less prone to reporting error. Our empirical analyses find that industries with extensive business dealings with the government behave very similar to those industries without government dealings in terms of women's entrepreneurship after the reform. Interaction elasticities are very close to zero and statistically insignificant. In summary, these inquiries suggest that direct access to government business due to female political leaders cannot account for a big portion of the entrepreneurship increases observed.

\section{Potential Channel: Access to Finance}

A third potential channel is that the political reservations led to a better financing environment for women entrepreneurs, perhaps due to the encouragement of microfinance organizations that served women-owned establishments. In the introduction, we noted in particular the connection established by Beaman et al. (2010) between the political reservations and the formation of selfhelp groups by women. These groups possessed stronger financial backing and bank services than before the reforms. Beaman et al. (2010) do not take a strong stance about whether the financing was a key feature or not. We further investigate in our study through an examination of external financing for women entrepreneurs (which overlaps with but is also distinct from the savings and lending enabled by self help groups).

We investigated the financing channel in multiple ways. These results suggest to us that improved financing likely explains some of the increase in entrepreneurship that we observe, but 
also emphasizes that financing (at least to the extent we can measure it) does not account for the majority of the increase in entry. It is clear that more women-owned establishments with financial backing enter after the reforms, but this increase is only part of a general expansion for female entrepreneurship, rather than the sole driver.

The NSSO collects data on external financing of unorganized establishments. ${ }^{2}$ A baseline descriptive point is that only $2 \%-3 \%$ of female-owned businesses in a typical year report using external finance (9\%-10\% for male-owned businesses). This statistic is again informative. While it is possible that many latent women entrepreneurs are precluded from entry due to poor financial conditions, we should also not be surprised if much of the entry occurs in a way that does not display a connection to external finance, at least as our data can measure it. ${ }^{3}$

The first econometric evidence is in Table 3 when we segment entrepreneurs into groups based upon whether or not they are using external finance. The group not reporting external financing both accounts for most of the sample and also has the higher elasticity response. While we do observe some tentative evidence of an increase in firms supported by external finance, the bulk of the entry is occurring elsewhere.

A second approach tests whether the entry response is disproportionately stronger in industries that were more dependent on external finance in 1994. This approach has been used frequently since Rajan and Zingales (1998) to test for the importance of external finance channels in economic outcomes. It again has the advantage of not requiring direct observation of loans, just the correct ordering of industries. These regressions are reported in Column 7 of Table 4. There is a positive elasticity of 0.1 with a t-statistic greater than one. There thus appears to be more traction to this story than the previous two, but at the same time, the financing interactions are far less than those for the other industry dimensions emphasized in Table 4.

Finally, the aggregate entry rates potentially mix two things: 1) ability to get loans conditional on establishment type with 2) changes in the type of establishments. Especially as

\footnotetext{
${ }^{2}$ External finance is defined to include any loans from central- and state-level term-lending institutions, governments (central, state, and local bodies), banks and societies (public sector, commercial, and co-operative), other institutional agencies, money lenders, business partner(s), suppliers, contractors, friends and relatives, and lenders not otherwise specified.

${ }^{3}$ Moreover, the share of new female businesses reporting external financing declines from $7 \%$ in 1994 to $4 \%$ in 2005 . The share of male entrants reporting external financing grew over the same period, from $16 \%$ to $17 \%$.
} 
much of the entry is occurring at the bottom of the establishment size distribution, it could be that financing overall plays a role that is obscured by the shifting composition of business types. To assess, we estimated a series of regressions at the establishment level with outcome variables like loan access and interest rates. This approach allowed us to control for establishment traits, and the results again pointed to a limited role.

It appears that financing followed the increased entry rates, rather than finance playing a causal role. This does not, of course, suggest that financing is not important, just as conversations about U.S. entrepreneurship often focus on financial constraints even though many firms do not take on external financing. But the patterns do suggest that the entrepreneurship stimulated by the political reservations had a broader foundation than this particular mechanism and that many of the very small establishments created did not rely on loans for launching their businesses.

\section{Local Industrial Networks and Neutral Channels}

In a study of spatial entry patterns, Ghani et al. (2013a) observe that female entrepreneurship in India is generally stronger in districts and industries where incumbent women-owned enterprises exist. Moreover, this study documents substantial and specific cross-industry interactions from women's business ownership in related industries due to the channels highlighted in the agglomeration literature (e.g., customer-supplier industries, industries that share similar labor needs). These cross-industry interactions suggest that much of the aid to new women entrepreneurs from the presence of existing women-owned businesses comes through economic exchanges such as access to inputs and sales opportunities. ${ }^{4}$ The household scale of these new establishments following the political reforms is a more novel pattern and follows partly from the fact that most women-owned establishments in unorganized manufacturing are household based.

\footnotetext{
${ }^{4}$ These analyses using the agglomeration frameworks of Ellison et al. (2010) and Glaeser and Kerr (2009). Rosenthal and Strange (2012) document a similar spatial segmentation pattern for female-owned businesses in the United States. In a similar spirit, Mandorff (2007) traces out the occupational and industry segregation of immigrant entrepreneurs in the United States, which he relates to a model of social interactions, scale economies, and sectorspecific skills.
} 


\section{Appendix References}

Ellison, Glenn, Edward Glaeser, and William Kerr, "What Causes Industry Agglomeration? Evidence from Coagglomeration Patterns", American Economic Review 100 (2010), 1195-1213.

Ghani, Ejaz, Ravi Kanbur, and Stephen D. O'Connell, "Urbanization and Agglomeration Benefits: Gender Differentiated Impacts on Enterprise Creation in India's Informal Sector", World Bank Working Paper 6553 (2013).

Glaeser, Edward, and William Kerr, "Local Industrial Conditions and Entrepreneurship: How Much of the Spatial Distribution Can We Explain?", Journal of Economics and Management Strategy 18:3 (2009), 623-663.

Mandorff, Martin, “Social Networks, Ethnicity, and Occupation”, Working Paper (2007).

Rajan, Raghuram, and Luigi Zingales, "Financial Dependence and Growth", American Economic Review $88: 3$ (1998), 559-586. 


\section{App. Fig. 1: Alternative age profiles for Figure 4}

\section{Age distr. of establishments $(A, B)$ and women's shares by age group (C,D)}

A. CDF distribution of women-owned establishments

in 1994 across age categories, state averages

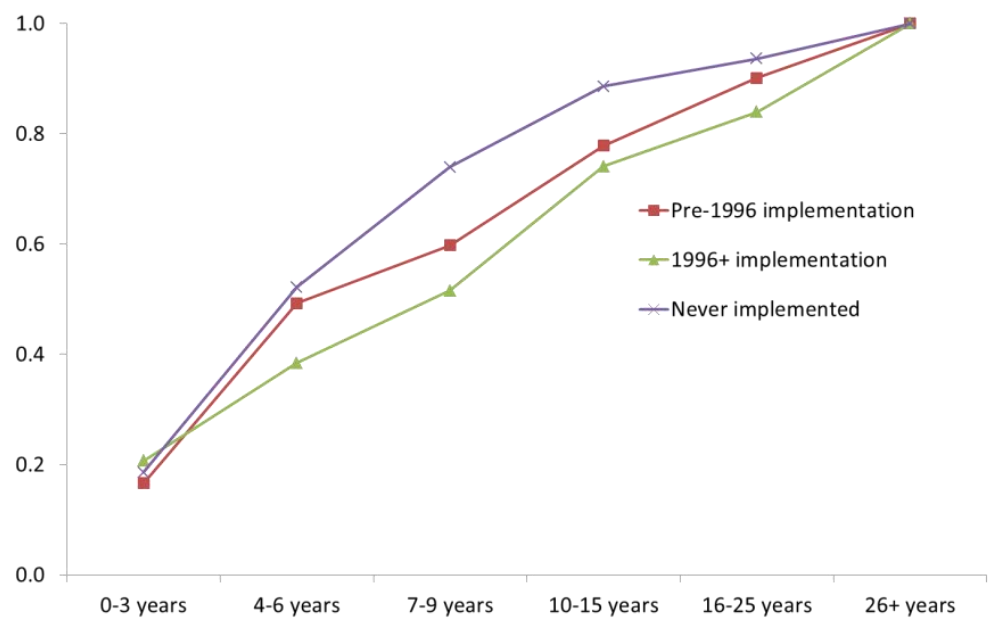

C. Share of establishments in age category that are owned by women in 1994, state averages

0.4

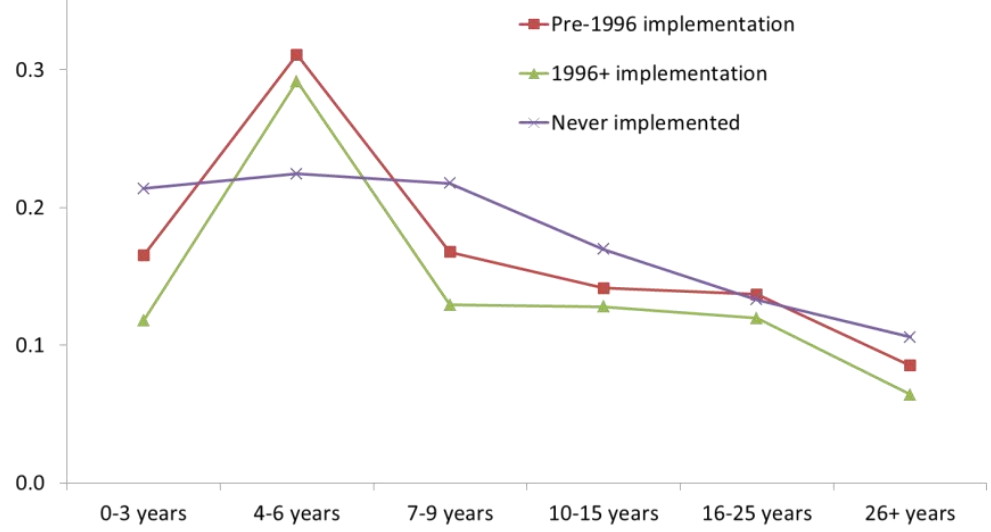

B. CDF distribution of male-owned establishments in 1994 across age categories, state averages

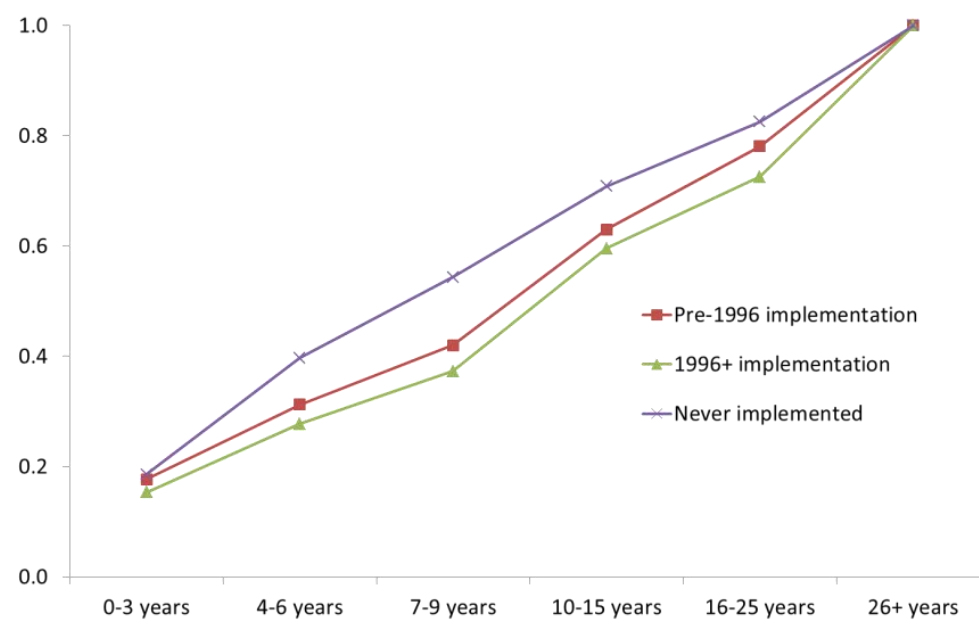

D. Normalized share of establishments in age category that are owned by women in 1994, state averages

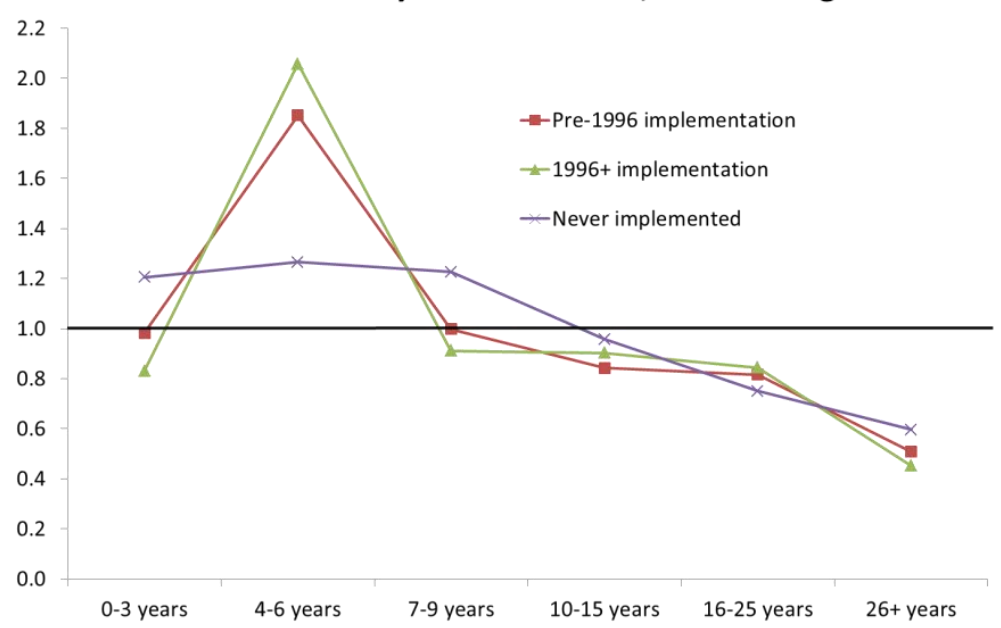




\section{App. Fig. 2: Relative entry rates around implementation dates}

\section{Raw women-to-men entrepreneurship ratio by state relative to reservations implementation}

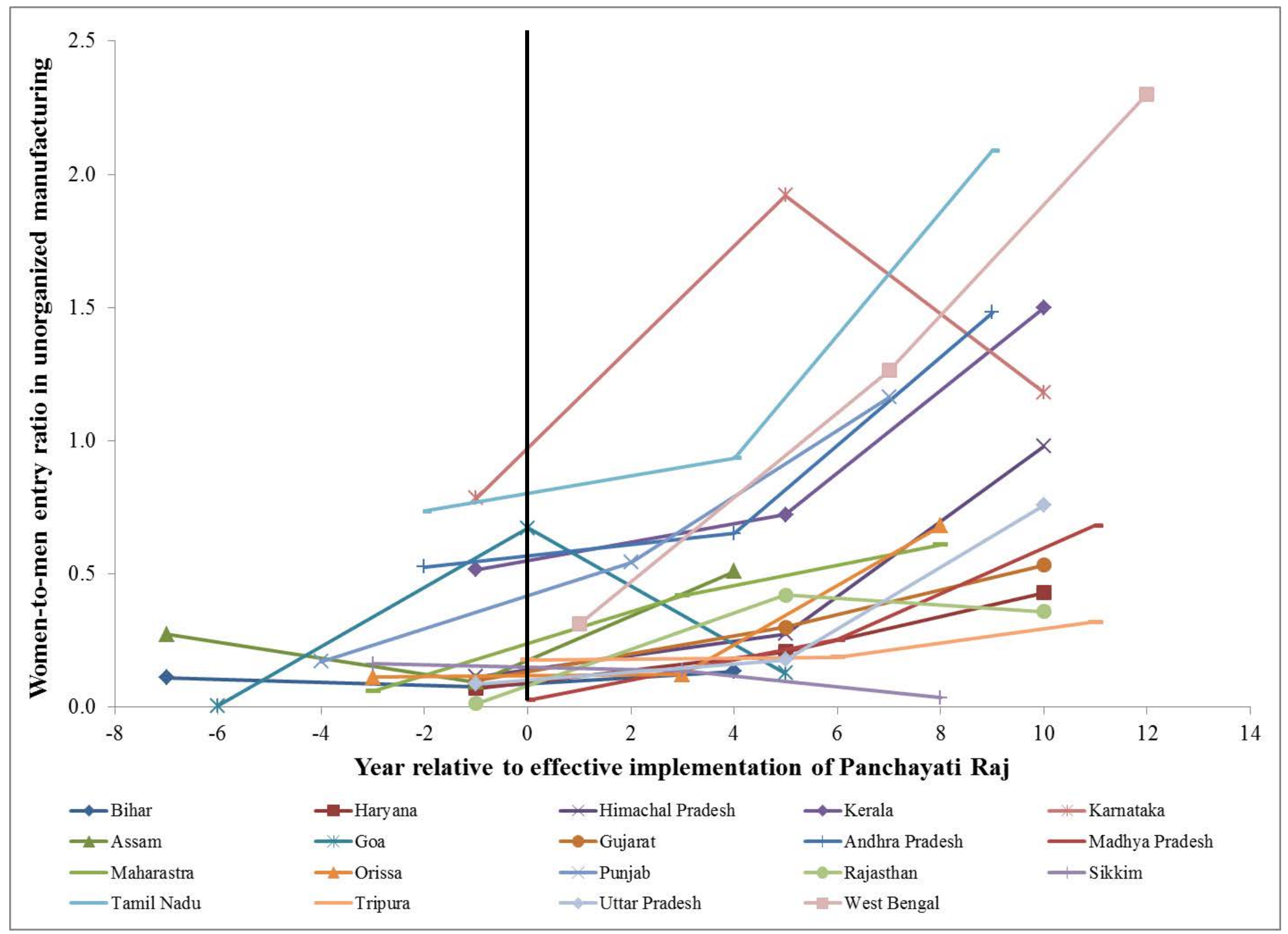




\section{App. Table 1: Effective implementation by state of political reservations}

State

Year of 73rd CAA enforcement

First election with mandated

reservations

\begin{tabular}{lll}
\hline Andhra Pradesh* & 1994 & 1996 \\
Arunachal Pradesh & 1997 & 2003 \\
Assam & 1994 & 2001 \\
Bihar & 1993 & 2001 \\
Chhattisgarh & 1997 & 2005 \\
Goa & 1995 & 2000 \\
Gujarat & 1997 & 1995 \\
Haryana & 1994 & 1995 \\
Himachal Pradesh & 1994 & 1995 \\
Karnataka* & 1993 & 1995 \\
Kerala & 1994 & 1995 \\
Madhya Pradesh & 1994 & 1994 \\
Maharashtra & 1994 & 1997 \\
Manipur & 1994 & 1997 \\
Orissa & 1996 & 1997 \\
Punjab & 1994 & 1998 \\
Rajasthan & 1994 & 1995 \\
Sikkim & 1993 & 1997 \\
Tamil Nadu & 1994 & 1996 \\
Tripura & 1994 & 1994 \\
Uttar Pradesh & 1994 & 1995 \\
Uttarakhand & 1994 & 1996 \\
West Bengal & 1993 & 1993
\end{tabular}

UTs and States not under purview of 73rd Act Amendment

A\&N Islands

1995

Chandigarh

1998

Dadra \& Nagar Haveli

1995

Daman \& Diu

1995

Lakshadweep

1997

Meghalaya

$\mathrm{n} / \mathrm{a}$

Mizoram

$\mathrm{n} / \mathrm{a}$

Nagaland

$\mathrm{n} / \mathrm{a}$

Delhi

$\mathrm{n} / \mathrm{a}$

Pondicherry

not held

Jharkhand

not held

Jammu \& Kashmir

not held

Source: Figure 1.1, Study on EWRs in Panchayati Raj Institutions, Ministry of Panchayati Raj, GOI (2008). Notes: Table displays implementation of nationally-mandated political reservations. *: Andhra Pradesh and Karnataka had state-level mandated political reservations prior to the Amendments. "n/a" denotes that the states of Meghalaya, Mizoram and Nagaland, and the national capital territory of Delhi are excluded from the purview of the 73rd Amendment. "not held" denotes states have not held elections subject to 73rd Amendment provisions up to this point. 
App. Table 2: Tests for pre-trends in women's employment in manufacturing from 1989 to 1994

\begin{tabular}{|c|c|c|c|c|c|c|c|c|}
\hline & $\begin{array}{l}\text { ASI: Log } \\
\text { growth in } \\
\text { women's } \\
\text { manufacturing } \\
\text { employment }\end{array}$ & $\begin{array}{l}\text { ASI: Change } \\
\text { in share of } \\
\text { manufacturing } \\
\text { employees that } \\
\text { are women }\end{array}$ & $\begin{array}{l}\text { NSS: Log } \\
\text { growth in } \\
\text { women's } \\
\text { manufacturing } \\
\text { employment }\end{array}$ & $\begin{array}{l}\text { NSS: Change } \\
\text { in share of } \\
\text { manufacturing } \\
\text { employees that } \\
\text { are women }\end{array}$ & $\begin{array}{l}\text { NSS Household } \\
\text { Surveys: Log } \\
\text { growth in } \\
\text { women's wage } \\
\text { manufacturing } \\
\text { employment }\end{array}$ & $\begin{array}{c}\text { NSS Household } \\
\text { Surveys: Change } \\
\text { in share of wage- } \\
\text { earning } \\
\text { manufacturing } \\
\text { employees that } \\
\text { are women }\end{array}$ & $\begin{array}{l}\text { NSS Household } \\
\text { Surveys: Log } \\
\text { growth in } \\
\text { women's OAE } \\
\text { manufacturing } \\
\text { employment }\end{array}$ & $\begin{array}{l}\text { NSS Household } \\
\text { Surveys: Change } \\
\text { in share of OAE } \\
\text { manufacturing } \\
\text { employees that } \\
\text { are women }\end{array}$ \\
\hline & $(1)$ & $(2)$ & $(3)$ & $(4)$ & $(5)$ & $(6)$ & $(7)$ & $(8)$ \\
\hline & \multicolumn{8}{|c|}{ A. Estimation at state level } \\
\hline $\begin{array}{l}\text { Year of first election } \\
\text { under 73rd Amendment }\end{array}$ & $\begin{array}{c}0.02182 \\
(0.07430)\end{array}$ & $\begin{array}{c}0.00025 \\
(0.00308)\end{array}$ & $\begin{array}{c}0.01663 \\
(0.05973)\end{array}$ & $\begin{array}{l}-0.00507 \\
(0.01420)\end{array}$ & $\begin{array}{c}0.20612 \\
(0.21499)\end{array}$ & $\begin{array}{c}0.00451 \\
(0.00556)\end{array}$ & $\begin{array}{c}0.14174 \\
(0.23612)\end{array}$ & $\begin{array}{c}0.02193 \\
(0.02658)\end{array}$ \\
\hline \multirow[t]{2}{*}{ Observations } & 23 & 23 & 26 & 26 & 26 & 26 & 26 & 26 \\
\hline & \multicolumn{8}{|c|}{ B. Estimation at state-industry level } \\
\hline $\begin{array}{l}\text { Year of first election } \\
\text { under 73rd Amendment }\end{array}$ & $\begin{array}{l}-0.01016 \\
(0.02368)\end{array}$ & $\begin{array}{c}0.00092 \\
(0.00229)\end{array}$ & $\begin{array}{c}0.04646 \\
(0.03693)\end{array}$ & $\begin{array}{c}0.00272 \\
(0.00293)\end{array}$ & $\begin{array}{l}-0.00257 \\
(0.04772)\end{array}$ & $\begin{array}{c}0.00523 \\
(0.00405)\end{array}$ & $\begin{array}{c}0.04183 \\
(0.07501)\end{array}$ & $\begin{array}{c}0.00748 \\
(0.00641)\end{array}$ \\
\hline Observations & 874 & 871 & 772 & 772 & 374 & 298 & 374 & 304 \\
\hline
\end{tabular}

Notes: Regressions check for pre-trends in women's employment in manufacturing during the 1989-1994 period before the elections began. Estimations in Panel A are similar to Figure 2 in looking at patterns at the state level. Estimations in Panel B are similar to Figure 3 in looking at patterns at the state-industry level. Regressions include a unreported constant and report robust standard errors. All R2 values are less than 0.01 .,+++++ , and + indicate statistical significance at a $1 \%, 5 \%$, and $10 \%$ level, respectively. 
App. Table 3: Estimates in Figure 5

\begin{tabular}{lcc}
\hline & $\begin{array}{c}\text { Log count of new women- } \\
\text { owned businesses }\end{array}$ & $\begin{array}{c}\text { Log count of new male-owned } \\
\text { businesses }\end{array}$ \\
\cline { 2 - 3 }$(0,1)$ 1-3 years before a state implements political reservations & $(1)$ & $(2)$ \\
& 0.046 & $-0.494++$ \\
$(0,1)$ 0-1 years after a state implements political reservations & $(0.183)$ & $0.206)$ \\
& 0.086 & $(0.265)$ \\
$(0,1)$ 2-4 years after a state implements political reservations & $(0.242)$ & 0.040 \\
& $0.410+$ & $(0.278)$ \\
$(0,1)$ 5+ years after a state implements political reservations & $(0.245)$ & -0.107 \\
Observations & 0.407 & $(0.309)$ \\
Adjusted R-squared & $(0.263)$ & 3606 \\
Controls & 3606 & 0.768 \\
Notes: See Figure 5. & 0.732 & State x industry and Industry x year fixed effects
\end{tabular}

Notes: See Figure 5. 
Share of

Share of

Industry

establishments owned by women and located

24 Chemicals and Chemical Products

by women

in households

16 Tobacco Products

21 Paper and Paper Products

$68 \%$

$43 \%$

$36 \%$

$32 \%$

25 Rubber and Plastic Products

$18 \%$

$15 \%$

20 Wood and Products of Wood and Cork, except Furniture; Articles of Straw and Plating Materials

18 Wearing Apparel; Dressing and Dyeing of Fur

$12 \%$

36 Furniture; Manufacturing N.E.C.

15 Food Products and Beverages

22 Publishing, Printing and Reproduction of Recorded Media

19 Tanning and Dressing of Leather; Luggage, Handbags Saddlery, Harness and Footwear

35 Other Transport Equipment

26 Other Non-Metallic Mineral Products

33 Medical, Precision and Optical Instruments, Watches and Clocks

27 Basic Metals

29 Machinery and Equipment N.E.C.

31 Electrical Machinery and Apparatus N.E.C.

28 Fabricated Metal Products, Except Machinery and Equipment

32 Radio, Television and Communication Equipment and Apparatus

34 Motor Vehicles, Trailers and Semi-Trailers

23 Coke, Refined Petroleum Products and Nuclear Fuel

30 Office, Accounting, Computing Machinery 
App. Table 5: Variations on Table 4's interaction approach for industry traits

\begin{tabular}{|c|c|c|c|c|c|c|c|c|}
\hline & \multicolumn{8}{|c|}{ DV is log count of new women-owned establishments in unorganized sector by state-industry } \\
\hline & $(1)$ & $(2)$ & (3) & (4) & $(5)$ & $(6)$ & $(7)$ & $(8)$ \\
\hline $\begin{array}{l}(0,1) \text { state has political reservations } \\
\mathrm{x} \log \text { women } \mathrm{HH} \text { share }\end{array}$ & $\begin{array}{c}0.399+++ \\
(0.135)\end{array}$ & & & & $\begin{array}{l}0.390+++ \\
(0.134)\end{array}$ & & & \\
\hline $\begin{array}{l}(0,1) \text { state has political reservations } \\
\mathrm{x} \text { women } \mathrm{HH} \text { share in raw form }\end{array}$ & & $\begin{array}{c}3.097++ \\
(1.257)\end{array}$ & & & & $\begin{array}{c}3.038++ \\
(1.224)\end{array}$ & & \\
\hline $\begin{array}{l}(0,1) \text { state has political reservations } \\
\mathrm{x} \text { women } \mathrm{HH} \text { share in unit standard deviations }\end{array}$ & & & $\begin{array}{c}0.416++ \\
(0.169)\end{array}$ & & & & $\begin{array}{c}0.408++ \\
(0.165)\end{array}$ & \\
\hline $\begin{array}{l}(0,1) \text { state has political reservations } \\
\mathrm{x}(0,1) \text { women } \mathrm{HH} \text { share in } 33-66 \text { th percentile }\end{array}$ & & & & $\begin{array}{l}0.510+ \\
(0.296)\end{array}$ & & & & $\begin{array}{l}0.490+ \\
(0.297)\end{array}$ \\
\hline $\begin{array}{l}(0,1) \text { state has political reservations } \\
\mathrm{x}(0,1) \text { women } \mathrm{HH} \text { share above } 66 \text { th percentile }\end{array}$ & & & & $\begin{array}{c}0.835++ \\
(0.347)\end{array}$ & & & & $\begin{array}{c}0.810++ \\
(0.347)\end{array}$ \\
\hline $\begin{array}{l}\text { DV analogue for male-owned } \\
\text { establishments in state-industry-year }\end{array}$ & & & & & $\begin{array}{c}0.096+++ \\
(0.031)\end{array}$ & $\begin{array}{c}0.096+++ \\
(0.031)\end{array}$ & $\begin{array}{c}0.096+++ \\
(0.031)\end{array}$ & $\begin{array}{c}0.096+++ \\
(0.031)\end{array}$ \\
\hline Observations & 3606 & 3606 & 3606 & 3606 & 3606 & 3606 & 3606 & 3606 \\
\hline Adjusted R-squared & 0.738 & 0.738 & 0.738 & 0.737 & 0.740 & 0.741 & 0.741 & 0.740 \\
\hline Controls & \multicolumn{8}{|c|}{ State $\mathrm{x}$ industry, State $\mathrm{x}$ year, and Industry $\mathrm{x}$ year fixed effects } \\
\hline
\end{tabular}

Notes: See Table 4. Columns 1 and 5 report the baseline estimations from Table 4 that consider interactions with the log share of unorganized establishments that are household-based (HH) and women-owned in 1994. Columns 2 and 6 and Columns 3 and 7 consider shares in their raw formats and expressed as unit standard deviations, respectively. Columns 4 and 8 consider indicators for the middle and high portions of the distribution. All interactions are calculated with 1994 industry data. 
App. Table 6: Primary activity of women and earnings

\begin{tabular}{cccccc}
\hline & 1987 & 1993 & 1999 & 2004 & 2009 \\
\cline { 2 - 5 } & $(1)$ & $(2)$ & $(3)$ & $(4)$ & $(5)$ \\
\hline
\end{tabular}

A. Share of women's activity over 1987-2009 period

Domestic activities

Agriculture and mining

Manufacturing

Services and transportation

Agriculture and mining

Manufacturing

Services and transportation

$\begin{array}{ccccc}60 \% & 64 \% & 63 \% & 60 \% & 68 \% \\ 29 \% & 27 \% & 27 \% & 28 \% & 21 \% \\ 3 \% & 3 \% & 3 \% & 4 \% & 3 \% \\ 6 \% & 6 \% & 6 \% & 7 \% & 7 \%\end{array}$

B. Average monthly earnings for workers listing main activity as OAE (2005 constant INR)

$\begin{array}{lllll}162 & 155 & 195 & 188 & 298 \\ 145 & 191 & 198 & 173 & 253 \\ 251 & 195 & 179 & 264 & 356\end{array}$

C. Average monthly earnings for workers listing main activity as wage work (2005 constant INR)

\begin{tabular}{lccccc} 
Agriculture and mining & 237 & 352 & 442 & 499 & 695 \\
Manufacturing & 390 & 476 & 563 & 541 & 908 \\
Services and transportation & 862 & 819 & 1284 & 1164 & 1722 \\
\hline
\end{tabular}

Notes: Tabulations depict traits of women workers taken from household-level surveys. 